\title{
A Casus Omissus in Preventing Bankruptcy Fraud: Ordering a Search of a Debtor's Home
}

\author{
MiCHAEL D. SOUSA*
}

\begin{abstract}
Most individual debtors file for bankruptcy relief with honest intentions. Nonetheless, there is also an underside to the American bankruptcy law system that often goes unreported and ignored in the scholarly literature, namely, the commission of fraud by debtors who seek protection under the Bankruptcy Code. One of the ways in which fraud upon the bankruptcy system occurs is when debtors intentionally conceal assets from the bankruptcy process. Indeed, reported bankruptcy court decisions are rife with examples of debtors attempting to hide or shield assets from their creditors. Debtors who are discovered concealing assets are subject to certain civil remedies, such as the dismissal of their bankruptcy case or the denial of the discharge of their preexisting indebtedness. One of the ways to combat suspected fraud is to authorize a bankruptcy trustee to conduct a search of a debtor's residence to ensure compliance with the disclosure requirements of the Bankruptcy Code. The issue of a bankruptcy trustee's search of a debtor's home, and more particularly the intersection between the Bankruptcy Code and the Fourth Amendment to the U.S. Constitution, has been addressed in two prior court decisions. On these occasions, the courts permitted a bankruptcy trustee to search a debtor's home, albeit after the trustee first obtained a "search order."
\end{abstract}

Incredulously, the two courts failed to address whether they in fact had the authority to order such a remedy. The issue is not free from doubt. Unlike other federal statutes that specifically authorize an administrative search, the Bankruptcy Code does not provide a statutory scheme authorizing a search of a debtor's home to uncover concealed assets. Consequently, there is presently a casus omissus, or an "unprovided-for case," in federal bankruptcy law. Thus, the purpose of this Article is to address this gap by answering whether a bankruptcy court has the requisite authority to issue what is in effect a search warrant for a debtor's residence. I answer this question in the affirmative, and contend that a bankruptcy court can utilize two sources of authority to issue a search order of a debtor's home, namely, the Federal All Writs Act and $\$ 105$ of the Bankruptcy Code. While admittedly counterarguments exist for the reliance upon these two sources of authority, which are addressed herein, they do provide a reasonable basis for a bankruptcy court to order a search of a debtor's home.

\section{TABLE OF CONTENTS}

I. INTRODUCTION

II. BRIEF BACKGROUND ON THE MECHANICS OF CONSUMER BANKRUPTCY LAW

III. PRIOR DECISIONS PERMITTING A WARRANT-BASEd SEARCH OF A

*Assistant Professor of Law, University of Denver Sturm College of Law. 
DEBTOR'S RESIDENCE

IV. Prior DeCisions Disclaiming the AUthority OF A

BANKRUPTCY COURT TO ISSUE A SEARCH WARRANT

V. SOURCES OF AUTHORITY FOR A BANKRUPTCY COURT TO ISSUE A

WARRANT TO SEARCH A DEBTOR'S RESIDENCE.

A. The Federal All Writs Act as a Source of Statutory Authority.. 111

B. Section 105 of the Bankruptcy Code as a Source of Authority to Issue a Search Warrant

C. The Inherent Powers Doctrine as a Source of Authority for a Bankruptcy Court to Issue a Search Warrant ....................... 135



\section{INTRODUCTION}

It has been repeatedly noted that federal consumer bankruptcy law serves two distinct purposes: first, to provide an individual debtor with a "fresh start" in life free from preexisting indebtedness; and second, to enable the debtor's various creditors to recognize an equitable distribution of the debtor's available assets. ${ }^{1}$ While many, if not most, individual debtors file for bankruptcy protection with honest intentions, there is also an underside to the current American bankruptcy system that often goes unreported and ignored in the scholarly literature, namely, the commission of fraud by debtors who seek

${ }^{1}$ Richard E. Flint, Bankruptcy Policy: Toward a Moral Justification for Financial Rehabilitation of the Consumer Debtor, 48 WASH. \& LEE L. REV. 515, 515-16 (1991) ("The essence of our consumer bankruptcy law is the discharge. The discharge of a consumer debtor frees the debtor from the shackles of existing debt and places him on the economic treadmill once again - to earn, consume and borrow." (footnotes omitted)); Charles G. Hallinan, The "Fresh Start" Policy in Consumer Bankruptcy: A Historical Inventory and an Interpretive Theory, 21 U. RICH. L. REV. 49, 50 (1986) ("One firmly established tenet of time-worn bankruptcy lore holds, of course, that the bankruptcy system serves two functions: the protection and payment of creditors; and the provision of shelter and a 'fresh start' to overburdened debtors."); Thomas H. Jackson, The Fresh-Start Policy in Bankruptcy Law, 98 HARV. L. REV. 1393, 1393 (1985) ("The principle advantage bankruptcy offers an individual lies in the benefits associated with discharge. Unless he has violated some norm of behavior specified in the bankruptcy laws, an individual who resorts to bankruptcy can obtain a discharge from most of his existing debts in exchange for surrendering either his existing nonexempt assets or, more recently, a portion of his future earnings."); George $\mathrm{H}$. Singer, Section 523 of the Bankruptcy Code: The Fundamentals of Nondischargeability in Consumer Bankruptcy, 71 AM. BANKR. L.J. 325, 325 (1997) ("Bankruptcy law is grounded upon the public policy of freeing the honest, but unfortunate, debtor from the financial burdens of prepetition indebtedness and thereby allowing the debtor to make an unencumbered fresh start."); see also Kokoszka v. Belford, 417 U.S. 642, 645-46 (1974) (noting that "[i]t is the twofold purpose of the Bankruptcy Act to convert the estate of the bankrupt into cash and distribute it among creditors and then to give the bankrupt a fresh start with such exemptions and rights as the statute left untouched" (citing Burlingham v. Crouse, 228 U.S. $459,473(1913))$ ). 
protection under the Bankruptcy Code. More specifically, fraud upon the bankruptcy system is committed when debtors intentionally conceal the extent of their assets available for distribution to creditors. Reported bankruptcy court decisions are rife with examples of debtors attempting to hide or shield assets from their creditors. ${ }^{2}$ Indeed, inspections of debtors' homes by bankruptcy trustees have in the past proved fruitful for the discovery of undisclosed assets. ${ }^{3}$

To help combat the suspected fraudulent concealment of assets by debtors in bankruptcy, in a prior article I proposed a framework under which a bankruptcy trustee could conduct a warrantless search of a debtor's residence under the Fourth Amendment to the U.S. Constitution 4 upon suspicion that the debtor was attempting to commit fraud by failing to disclose assets to the

${ }^{2}$ See, e.g., United States v. Wagner, 382 F.3d 598, 602-03 (6th Cir. 2004) (debtor convicted under the criminal law for concealing an asset from the banknuptcy trustee); Vill. of San Jose v. McWilliams, 284 F.3d 785, 787-88 (7th Cir. 2002) (debtors denied discharge after attempting to transfer property prior to commencing bankruptcy); United States v. Cluck, 143 F.3d 174, 176 (5th Cir. 1998) ("Thus, before invoking the power of Title 11, he perceived that it might be useful to keep some Jaguars in reserve, some money within easy access, and, maybe, just for good measure, a few of his favorite things beyond the reach of his creditors and the bankruptcy court."); United States v. Christner, 66 F.3d 922, 923 (8th Cir. 1995) (debtor convicted under 28 U.S.C. $\S 152$ for concealing approximately $\$ 36,000$ from the bankruptcy proceeding); Boroff v. Tully (In re Tully), 818 F.2d 106, 107 (1st Cir. 1987) (debtor denied discharge for failing to disclose significant assets in the bankruptcy process); Stegeman v. United States, 425 F.2d 984, 985, 989 (9th Cir. 1970) (debtors convicted of violating 18 U.S.C. $\S 152$ after fraudulently transferring certain assets to third parties before the institution of an involuntary bankruptcy proceeding against them); United States v. Shapiro, 101 F.2d 375, 376, 380 (7th Cir. 1939) (debtor convicted of concealing money from the bankruptcy trustee); United States v. Conner, 25 F. Cas. 595, 595 (C.C.D. Mich. 1845) (No. 14,847) (debtor indicted under criminal law for failing to disclose certain assets in the bankruptcy proceeding); Youngman v. Bursztyn (In re Bursztyn), 366 B.R. 353, 362 (Bankr. D.N.J. 2007) (debtor attempted to conceal approximately $\$ 250,000$ worth of assets from the bankruptcy proceeding); U.S. Tr. v. Gardner (In re Gardner), 344 B.R. 663, 668 (Bankr. M.D. Fla. 2006) (debtor denied discharge for failing to disclose his interest in a corporation); Jeffrey M. Goldberg \& Assocs. v. Holstein (In re Holstein), 299 B.R. 211, 233 (Bankr. N.D. Ill. 2003) (debtor denied discharge for fraudulently concealing assets from the bankruptcy court); Roudebush v. Sharp (In re Sharp), 244 B.R. 889, 891 (Bankr. E.D. Mich. 2000) (debtor denied discharge for intentionally concealing assets from the bankruptcy court); Banc One, Tex., N.A. v. Braymer (In re Braymer), 126 B.R. 499, 503-04 (Bankr. N.D. Tex. 1991) (debtor denied discharge after exhibiting a pattern of behavior to hide assets from her creditors). This list simply serves as an illustration, and is certainly not exhaustive.

${ }^{3}$ See, e.g., In re Washington, 232 B.R. 814, 816-17 (Bankr. S.D. Fla. 1999) (after one of the debtor's children let the bankruptcy trustee into the debtor's house, the trustee discovered various previously undisclosed assets).

${ }^{4}$ The Fourth Amendment to the Constitution provides as follows:

The right of the people to be secure in their persons, houses, papers, and effects, against unreasonable searches and seizures, shall not be violated; and no Warrants shall issue but upon probable cause, supported by Oath or affirmation, and particularly describing the place to be searched, and the persons or things to be seized.

U.S. CONST. amend. IV. 
bankruptcy court. ${ }^{5}$ In short, I advanced the thesis that a bankruptcy trustee, though bound by the Fourth Amendment, can conduct a warrantless search of a debtor's home based upon three distinct theories, namely, that: (1) the bankruptcy process is akin to a "special needs" administrative search exception to the Fourth Amendment warrant requirement; (2) the bankruptcy law system amounts to a "closely regulated industry" under Fourth Amendment jurisprudence; and (3) a debtor impliedly consents to the search of her home based upon the intrusive nature of the bankruptcy process along with the trustee's statutory duties to investigate the financial affairs of the debtor. ${ }^{6}$

As noted in the prior article, the intersection of the Fourth Amendment and bankruptcy law, and, more precisely, the ability of a bankruptcy trustee to search a debtor's residence upon suspicion that the debtor is fraudulently concealing assets from the bankruptcy process, has been addressed in two prior reported decisions, Taunt v. Barman (In re Barman) ${ }^{7}$ and Youngman v. Bursztyn (In re Bursztyn). ${ }^{8}$ As will be discussed in more detail below, both decisions enabled a bankruptcy trustee to search a debtor's home; however, the two courts permitted the search only after the bankruptcy trustee first obtained a search order.

Perhaps incredulously, the Barman and Bursztyn courts both failed to address whether they in fact had the authority to order such a remedy. The issue is hardly free from doubt. Unlike other federal statutes that specifically contemplate or authorize an administrative search, such as the Occupational Safety and Health Act, ${ }^{9}$ the Bankruptcy Code does not provide a statutory scheme authorizing a search of a debtor's home to uncover concealed assets. Consequently, there is presently a casus omissus, or an "unprovided-for case," in federal bankruptcy law. ${ }^{10}$ Consequently, the purpose of this Article is to address this gap in answering whether a bankruptcy court even has the authority to issue what is in effect a search warrant for a debtor's residence, assuming one is required in order to comply with the Fourth Amendment.

I answer this inquiry in the affirmative, and contend that a bankruptcy court can utilize two sources of authority to issue such an order, namely, the Federal All Writs Act and $\S 105$ of the Bankruptcy Code. Another potential source of

${ }^{5}$ See Michael D. Sousa, A Delicate Balancing Act: Satisfying the Fourth Amendment While Protecting the Bankruptcy System from Debtor Fraud, 28 YALE J. ON REG. 367 (2011).

${ }^{6}$ Id. at 375 .

7252 B.R. 403 (Bankr. E.D. Mich. 2000).

8366 B.R. 353 (Bankr. D.N.J. 2007).

${ }^{9} 29$ U.S.C. $\$ 657$ (2006); see also 29 C.F.R. § 1903.4(a) (2011) (noting that an appropriate OSHA official can take action, including "compulsory process," to occasion a search of an employer's premises). "Compulsory process" has been interpreted to include ex parte search warrants. Amoco Oil Co. v. Marshall, 496 F. Supp. 1234, 1238 (S.D. Tex. 1980).

${ }^{10}$ Black's Law Dictionary defines "casus omissus" as "[a] situation not provided for by a statute or contract, and therefore governed by caselaw or new judge-made law." BLACK'S LAW DiCTIONARY 247 (9th ed. 2009). 
authority, namely, the "inherent powers doctrine," is also considered, though it appears unlikely that a bankruptcy court could rely on this "nebulous" doctrine. ${ }^{11}$ But even in arguing that the All Writs Act and $\S 105$ of the Code offer such authority, a point of caution is in order. Though these two statutes provide reasonable authority for a bankruptcy court to so act, admittedly, wellgrounded counterarguments do exist. Thus, my arguments herein do not escape criticism. But if this Article engenders a discussion on this important issue among the courts or scholars, or both, the time in drafting would prove well spent.

This Article will proceed in several parts. Part II provides the reader with a brief contextual overview of the consumer bankruptcy process. Part III discusses the prior court decisions permitting a warrant-based search of a debtor's home. Part IV then discusses the court decisions disclaiming the authority of a bankruptcy court to issue a search warrant. Next, Part V argues that the Federal All Writs Act and $\S 105$ of the Bankruptcy Code can serve as authority for a bankruptcy court to issue a search warrant for a debtor's home if the trustee suspects the concealment of assets from the bankruptcy process. This section also considers the potential authority under the inherent powers doctrine. Finally, Part VI offers a brief conclusion.

\section{BRIEF BACKGROUND ON THE MECHANICS OF CONSUMER BANKRUPTCY LAW ${ }^{12}$}

Individuals contemplating filing for bankruptcy protection can generally choose to file either for Chapter 7, Chapter 13, or Chapter 11. The ultimate decision of selecting a particular chapter of the Bankruptcy Code largely depends upon the debtor's financial status and the significance of her assets. The most common type of bankruptcy case for individual debtors is a liquidation proceeding governed by Chapter 7 of the Bankruptcy Code. ${ }^{13}$ Once a Chapter 7 bankruptcy petition is filed, ${ }^{14}$ the Bankruptcy Code mandates that a bankruptcy trustee be appointed to serve in the case. ${ }^{15}$ The primary function of a bankruptcy trustee in a Chapter 7 proceeding ${ }^{16}$ is to collect and liquidate

${ }^{11}$ See Eash v. Riggins Trucking Inc., 757 F.2d 557, 561 (3d Cir. 1985) (describing the inherent powers doctrine as "nebulous" and a "shadowy" concept).

12 This section is adapted from my prior article. See Sousa, supra note 5, at 375-78.

${ }^{13}$ Charles Jordan TABB, THE LAW OF BANKRUPTCY $\S 1.23$, at 92 ( $2 \mathrm{~d}$ ed. 2009) ("A chapter 7 liquidation bankruptcy case is the norm. The majority of all bankruptcy filings, over $60 \%$, are liquidation bankruptcies under chapter 7."); see also 11 U.S.C. $\$ \S 701-784$.

14 The commencement of a bankruptcy case is usually a voluntary act by the debtor. However, the Bankruptcy Code provides for the involuntary filing of a bankruptcy petition against a debtor, if certain conditions are met. See 6 COLLIER ON BANKRUPTCY $\uparrow 700.02$ (Alan N. Resnick \& Henry J. Sommer eds., 16th ed. 2010); see also 11 U.S.C. § 303(b).

15 See 11 U.S.C. $\$ \S 701-702$.

${ }^{16}$ See generally id. $\S 704$ (specifying duties of the trustee). 
"property of the estate" 17 that is otherwise not exempt from the bankruptcy process, and in turn to distribute any proceeds from the liquidation of the assets to creditors in accordance with the priority scheme set forth in the Bankruptcy Code. ${ }^{18}$

During the pendency of a bankruptcy case, creditors are enjoined, or "stayed," from most attempts to collect their claims from the debtor or the bankruptcy estate. ${ }^{19}$ In exchange for turning over any non-exempt assets to the bankruptcy trustee for eventual liquidation, the Chapter 7 debtor is permitted to retain her post-petition earnings free from the claims of her pre-bankruptcy creditors. ${ }^{20}$ The goal of a consumer debtor in a Chapter 7 bankruptcy proceeding is to obtain a discharge of her pre-petition indebtedness, ${ }^{21}$ which results in the extinguishment of the debtor's in personam liability for the debt. 22

In contrast to Chapter 7, Chapter 13 of the Bankruptcy Code enables individual debtors generally to retain their pre-petition assets in exchange for repaying a portion of their future disposable income to creditors through a court-approved repayment plan..$^{23}$ A Chapter 13 debtor is protected from the collection efforts of her creditors by virtue of the automatic stay while the plan of repayment is developed and thereafter approved by the court. ${ }^{24}$ In a Chapter 13 bankruptcy case, the Chapter 13 "standing trustee" serves as the principal

${ }^{17}$ Upon the filing of a bankruptcy petition a mythical bankruptcy "estate" is created that is comprised of "all legal or equitable interests of the debtor in property as of the commencement of the case." Id. §541(a)(1).

${ }^{18}$ In re Tarrant, 349 B.R. 870, 875 (Bankr. N.D. Ala. 2006) (“A 'Chapter 7 trustee's duty is to reduce to money the legal or equitable interests owned by the debtor in these various assets so that the proceeds may be distributed to unsecured creditors in accordance with Section 726."' (citing In re Talbert, 268 B.R. 811, 819 (Bankr. W.D. Mich. 2001))).

${ }^{19}$ See generally 11 U.S.C. $\$ 362$ (specifying ways in which a banknuptcy filing operates as a stay of creditor collection efforts).

${ }^{20} \mathrm{Id}$. $\S 541(\mathrm{a})(6)$ (including in property of the estate "[p]roceeds, product, offspring, rents, or profits of or from property of the estate, except such as are earnings from services performed by an individual debtor after the commencement of the case"); see also TABB, supra note $13, \S 1.1$, at 3 ("An individual debtor thus may keep his future earnings for himself, free from the claims of his pre-banknuptcy creditors.").

${ }^{21}$ Edwards v. Sieger (In re Sieger), 200 B.R. 636, 638 (Bankr. N.D. Ind. 1996) ("'The goal of all bankruptcy legislation is to achieve a just and equitable distribution of the estate to the creditors and to relieve the honest debtor of his debts, giving him a fresh start." (quoting In re Epstein, 39 B.R. 938, 941 (Bankr. D.N.M. 1984))).

${ }^{22}$ Notably, "a bankruptcy discharge extinguishes only one mode of enforcing a claimnamely, an action against the debtor in personam - while leaving intact another-namely, an action against the debtor in rem." Johnson v. Home State Bank, 501 U.S. 78, 84 (1991).

232 NANCY C. DREHER \& JOAN N. FEENEY, BANKRUPTCY LAW MANUAL § 13:1 (5th ed. 2009); see also In re McCollum, 348 B.R. 377, 393 (Bankr. E.D. La. 2006) ("As part of the deal a debtor makes with his or her creditors when electing to file under chapter 13, as opposed to chapter 7 , the debtor retains all pre-petition property in exchange for committing all post-petition disposable income to the payment of creditors under a plan of reorganization." (citing In re Burgie, 239 B.R. 406, 410 (B.A.P. 9th Cir. 1999))); In re Golek, 308 B.R. 332, 338 (Bankr. N.D. Ill. 2004).

${ }^{24}$ DREHER \& FEENEY, supra note $23, \S 13: 1$. 
administrator in the proceeding. ${ }^{25}$ Unlike the Chapter 7 trustee, the Chapter 13 trustee does not sell the debtor's property. Rather, the Chapter 13 trustee's main responsibility is to collect a debtor's plan payments and to distribute the funds to the creditors in accordance with the court-approved plan. ${ }^{26}$ That said, however, like the Chapter 7 trustee, the Chapter 13 trustee is also charged with the responsibility of investigating the financial affairs of the debtor and opposing the discharge of the debtor, if warranted. ${ }^{27}$ With certain limited exceptions, a Chapter 13 debtor will receive a discharge of preexisting debts only after all payments are made under the court-approved plan..$^{28}$

An individual debtor's fresh start is accomplished through the discharge of most of her pre-petition indebtedness. ${ }^{29}$ Unless the individual debtor violates a proscribed form of behavior contained within the Banknuptcy Code or developed through federal bankruptcy law, 30 an individual who files for bankruptcy relief can ordinarily obtain a discharge from the majority of her prepetition debts in exchange for surrendering any non-exempt assets. ${ }^{31}$

\author{
${ }^{25} I d . \S 13: 9$. \\ ${ }^{26} I d$. \\ 27 See 11 U.S.C. $\$ 1302$ (2006). \\ 28 See id. $\S 1328(a)$. \\ ${ }^{29}$ In perhaps the most cited recitation of the fresh start principle, the Supreme Court of \\ the United States stated as follows in Local Loan Co. v. Hunt:
}

One of the primary purposes of the bankruptcy act is to 'relieve the honest debtor from the weight of oppressive indebtedness and permit him to start afresh free from the obligations and responsibilities consequent upon business misfortunes.' This purpose of the act has been again and again emphasized by the courts as being of public as well as private interest, in that it gives to the honest but unfortunate debtor who surrenders for distribution the property which he owns at the time of bankruptcy, a new opportunity in life and a clear field for future effort, unhampered by the pressure and discouragement of pre[e]xisting debt.

Local Loan Co. v. Hunt, 292 U.S. 234, 244 (1934) (citation omitted); see also U.S. Dep't of Health \& Human Servs. v. Smith, 807 F.2d 122, 123-24 (8th Cir. 1986) ("The bankruptcy laws embody a congressional policy to free an honest debtor from his financial burdens and thus allow him to make an unencumbered fresh start." (citing Kokoszka v. Belford, 417 U.S. $642,645-46(1974))$ ).

${ }^{30}$ See generally 11 U.S.C. $\S 727$ (a); id. $\S 1328(a)$. The types of prohibited conduct that would lead to a denial of the discharge relate to either the debtor's behavior leading up to the bankruptcy filing or her conduct during the bankruptcy proceeding itself. For example, a court may deny a Chapter 7 debtor's discharge if she: (i) transferred or concealed any property from the bankruptcy process so as to defraud any creditor; (ii) transferred or destroyed property within one year before the filing date with the intent to hinder, delay, or defraud a creditor; (iii) transferred or destroyed "property of the estate" after the bankruptcy petition is filed; (iv) concealed, destroyed, mutilated or falsified any financial documents; (v) made a false oath or presented a false claim in connection with the bankruptcy case; or (vi) failed to obey any lawful order of the banknuptcy court. Id. $\S 727$ (a).

31 See Jackson, supra note 1, at 1393. 


\section{Prior Decisions Permitting a WarRant-Based Search of A DEBTOR'S RESIDENCE ${ }^{32}$}

As previously noted, to date only two reported decisions have squarely addressed the question of whether a bankruptcy trustee can conduct a search of a debtor's home, and its related intersection with the Fourth Amendment. Both decisions ultimately authorized a search of a debtor's home after the bankruptcy trustee first obtained a "search order" from the court.

The first reported decision to address the intersection of bankruptcy law and the Fourth Amendment is Taunt v. Barman (In re Barman) ${ }^{33}$ In Barman, Norman Barman filed a petition for Chapter 7 relief, ${ }^{34}$ and in his schedules accompanying the bankruptcy petition, Barman listed wearing apparel worth $\$ 500$ as his only asset. ${ }^{35}$ However, Barman was apparently engaged in a scheme to place his personal property beyond the reach of his creditors and to purchase parcels of real property in the names of others in order to avoid liability to his creditors. ${ }^{36}$ Upon learning of this plan, the bankruptcy trustee filed a complaint against Barman, alleging in part that he fraudulently transferred funds to his wife for the purchases of various homes and concealed assets belonging to the bankruptcy estate. ${ }^{37}$ In addition, the trustee sought to revoke Barman's discharge. ${ }^{38}$

The bankruptcy trustee subsequently filed an ex parte motion for an order authorizing the trustee to enter Barman's home in order to inspect, inventory, and appraise any property found within the home. ${ }^{39}$ The bankruptcy court

32 This section is adapted from my prior article. See Sousa, supra note 5, at 382-90.

33252 B.R. 403 (Bankr. E.D. Mich. 2000).

34 Id. at 407 .

${ }^{35} \mathrm{Id}$.

${ }^{36} \mathrm{Id}$.

${ }^{37} \mathrm{Id}$.

${ }^{38}$ Id.

${ }^{39}$ Barman, 252 B.R. at 407 . The need to request ex parte relief was premised on the trustee's belief that given Barman's past machinations of moving assets, a less than complete inventory would occur if the debtor received prior notice of any home inspection. Id. at 40910. In particular, the trustee's application to the court provided as follows:

The Trustee's counsel was informed, on December 17, 1999 that the Debtor had a trailer at his residence... that contained personal property of the Debtor and/or the Debtor's wife. This information was provided to the Trustee by a party that is involved with post-petition business litigation involving the Debtor and persons/entities related to the Debtor .... In addition to the existence of the trailer, the Trustee was informed that according to what was witnessed at the residence, including the condition of the house and the existence of a mobile home near the premises, it appeared that the Debtor and his family may be moving from that residence. The Trustee has expedited the filing of both an adversary proceeding against the Debtor and related parties and this motion to avoid the likely irreparable harm to the bankruptcy estate in light of the Debtor's history of flight and defiance of previous bankruptcy court orders.

Id. at 409 (citations omitted) (internal quotation marks omitted). 
granted the motion, and entered what was denominated as an "inspection order."40

Following the subsequent search, Barman attempted to suppress the evidence obtained by the bankruptcy trustee during the search of his home on the grounds that the search violated his rights against unreasonable searches and seizures under the Fourth Amendment. ${ }^{41}$ In ruling on the suppression motion, the Barman court first concluded that a bankruptcy trustee has a sufficiently close nexus to "government and its power that it is necessary and appropriate to apply to the trustee the [F]ourth [A]mendment limits on government power."42 After concluding that a bankruptcy trustee constitutes an actor bound by the Fourth Amendment, the court then considered the nature and scope of a debtor's expectation of privacy under the Fourth Amendment. On this note, the bankruptcy court observed that debtors have a significantly reduced expectation of privacy in their homes, which "is a natural consequence of the substantial and detailed disclosures that are inherent in the bankruptcy process." 43

Despite this conclusion, however, the bankruptcy court did not go so far as to hold that a debtor has no reasonable expectation of privacy in her residence or personal property upon filing for bankruptcy relief. ${ }^{44}$ For the Barman court, three considerations militated against such a finding. First, the court noted that unlike a debtor's bankruptcy petition and accompanying financial disclosures and schedules which are publicly obtainable documents, an inspection of a debtor's home is not open to the public domain. ${ }^{45}$ Second, the court observed that "nothing in the Bankruptcy Code states or implies an obligation upon a debtor to permit an inspection by a trustee without a court order." 46 That is, "[n] either the obligation to file written disclosures nor the obligation to appear at the creditors' meeting relates at all to an inspection of a debtor's residence by the trustee." 47 The court further noted that a debtor's statutory obligation to cooperate with a bankruptcy trustee in the administration of the estate "has never been construed to require a debtor to allow an inspection without a court order."48 Third, the court held that although the Bankruptcy Code causes the debtor's property to be brought into the bankruptcy estate upon the filing of a bankruptcy petition, "the estate's interest in the property is quite limited, both in time and in function, and the debtor retains a substantial practical and beneficial interest in that property even while it is temporarily property of the estate."49
${ }^{40}$ Id. at 410.
${ }^{41}$ Id.
42 Id. at 413.
${ }^{43}$ Id. at 414 .
${ }^{44} I d$.
45 Barman, 252 B.R. at 414.
${ }^{46}$ Id.
${ }^{47} \mathrm{Id}$.
${ }^{48} \mathrm{Id}$.
${ }^{49}$ Id . at 415 . 
Having determined that a bankruptcy trustee is bound by the Fourth Amendment and that a debtor in bankruptcy still possesses a reduced expectation of privacy in her residence, the Barman court then defined the specific protections to which a debtor in bankruptcy is entitled under the Fourth Amendment. ${ }^{50}$ Relying upon Fourth Amendment jurisprudence in the context of administrative inspections and searches, the court employed the balancing test espoused by the Supreme Court in Camara v. Municipal Court, ${ }^{51}$ namely, weighing the need to search against the invasion of privacy and disruption engendered by the search itself. ${ }^{52}$

In balancing the competing interests of the bankruptcy system for full and candid disclosures by debtors against an individual's expectation of privacy in the home, the Barman court conceded that "experience demonstrates that in carrying out the trustee's obligations under the Bankruptcy Code, the trustee may need to inspect a debtor's residence for property of the estate." 53 Significantly, and again as the court recognized, "such a need may arise when, as here, the trustee has reason to believe that there are undisclosed assets to be administered for the benefit of the estate." 54 The court further observed that bankruptcy trustees may have no way to fulfill the statutory obligation to account for all of the property of the estate without an inspection of a debtor's residence. ${ }^{55}$ To this end, the Barman court concluded that as a result of a debtor's obligation to disclose all of her assets and cooperate with the bankruptcy trustee as a condition to receiving a discharge of indebtedness, a search of a debtor's home may "be a crucial part of the process and therefore a matter of substantial need."56 Perhaps more strikingly, the court concluded "that a procedure for an inspection order in bankruptcy would be an ordinary part of the judicial and administrative processes of bankruptcy." 57 Because the court believed that "allowing trustees to perform inspections without a court order would be 'out of place," 58 the Barman court permitted the trustee's search after entering a carefully tailored "inspection order." 59

50 Id.

51387 U.S. 523, 534, 536-37 (1967).

52 Barman, 252 B.R. at 416.

${ }^{53} \mathrm{Id}$.

${ }^{54} \mathrm{Id}$.

55 Id. at 417 .

56 Id.

${ }^{57} \mathrm{Id}$.

58 Barman, 252 B.R. at 417 (citing Wyman v. James, 400 U.S. 309, 324 (1971)).

${ }^{59} \mathrm{Id}$. at 418 . The inspection order entered by the court contained the following restrictions. First, the bankruptcy trustee must file a written motion requesting an inspection order setting forth the facts establishing reason to believe that there is property of the estate on the premises to be inspected. Second, the motion should presumptively be filed according to the regular motion process utilized by the court, that is, upon notice and an opportunity for the debtor to be heard. Third, the motion should seek to conduct the search during regular business hours, in the debtor's presence, and without forcible entry. Fourth, the contemplated order must identify the premises to be inspected. Fifth, and finally, any 
While the Barman court recognized the need for a bankruptcy trustee to comply with the requirements of the Fourth Amendment and procure what is tantamount to a search warrant of a debtor's home prior to engaging in any search, the court failed to articulate its source of authority for issuing such an order.

Approximately seven years after the Barman decision, another court issued its opinion in Youngman v. Bursztyn (In re Bursztyn). ${ }^{60}$ In Bursztyn, Miriam Bursztyn filed a voluntary petition for bankruptcy relief under Chapter 7 of the Bankruptcy Code. ${ }^{61}$ On her bankruptcy petition, Bursztyn listed as her only assets: a bank account, costume jewelry, nominal household goods and clothing, a claim against her former husband, and two used luxury vehicles. ${ }^{62}$ During the course of the bankruptcy trustee's investigation into Bursztyn's financial affairs, however, the trustee obtained two written judicial decisions rendered in the Debtor's ongoing state court divorce proceedings that belied the disclosures made by Bursztyn on her bankruptcy petition and accompanying schedules. ${ }^{63}$ In short, the state court record indicated that Bursztyn retained a significant collection of artwork and jewelry, items not disclosed on her bankruptcy petition and schedules. ${ }^{64}$

Based upon this development, the trustee applied ex parte to the bankruptcy court for an order authorizing her to enter Bursztyn's residence "with the assistance of the United States Marshal's Service, her counsel, and an appraiser to search for, seize, and appraise estate property located within the residence."65. After evaluating the trustee's request, the bankruptcy court entered an order authorizing the bankruptcy trustee, her counsel, an appraiser, and representatives of the U.S. Marshals Service to enter Bursztyn's residence during normal business hours to search for, seize, and appraise any uncovered assets, namely, artwork and jewelry. ${ }^{66}$ The bankruptcy trustee subsequently uncovered various fine jewelry and artwork amounting to approximately $\$ 243,000.00$, located in various places in the home, including in laundry bags and suitcases tucked away in the bottom of the debtor's bedroom closet. ${ }^{67}$ Bursztyn thereafter filed an opposition to the bankruptcy trustee's actions, but the court concluded that the bankruptcy trustee's search of her residence was reasonable under the circumstances, and thus, constitutional. ${ }^{68}$

warrant granted by the court would not authorize the seizure of any property, only the inspection, inventory, and appraisal of such property. Id.

60366 B.R. 353 (Bankr. D.N.J. 2007).

61 Id. at 355 .

$62 \mathrm{Id}$. at 356.

${ }^{63} \mathrm{Id}$. The second of these state court matrimonial decisions was issued only three months before Bursztyn filed her bankruptcy petition. Id.

${ }^{64} \mathrm{Id}$. at 358-59.

${ }^{65} \mathrm{Id}$. at 360 .

66 Bursztyn, 366 B.R. at $360-61$.

${ }^{67} \mathrm{Id}$. at $361-62$.

${ }^{68} \mathrm{Id}$. at $373-74$. 
The analysis in Bursztyn largely reflected the legal conclusions reached by the Barman decision with respect to a debtor's expectations of privacy under the Fourth Amendment. Moreover, the Bursztyn court explicitly adopted the balancing test created by the U.S. Supreme Court in determining the reasonableness of a search in instances of civil administrative searches. ${ }^{69}$ Furthermore, like Barman, the Bursztyn decision recognized that in performing her duties, a bankruptcy trustee may need to inspect a debtor's residence for potentially undisclosed assets of the estate to be administered for the benefit of creditors. ${ }^{70}$ Indeed, as both decisions acknowledge, "a trustee may have no alternative in carrying out her statutory obligations to marshal and account for all of the property of the estate without an inspection of the debtor's residence." 71 However, like Barman, the Bursztyn court did not reflect on its ability to issue a search order for a debtor's residence. The decision is silent on this front.

Nonetheless, Barman and Bursztyn affirmatively demonstrate the necessity of sometimes permitting a bankruptcy trustee to conduct a search of a debtor's home in order to uncover potentially undisclosed assets belonging to the bankruptcy estate. The unexamined inquiry in both judicial decisions and in the existing scholarly literature is whether a bankruptcy court can even order a search of a debtor's home. As noted in Barman, no provision in the Bankruptcy Code or Federal Rules of Bankruptcy Procedure currently authorizes a search of a debtor's home as incident to a bankruptcy trustee's duties to investigate the financial affairs of a debtor. Adding to the dilemma is the fact that bankruptcy courts are not in accord as to whether they possess the authority to order a search of a debtor's residence.

\section{PRIOR DECISIONS DisclaIMING THE AUTHORITY OF A BANKRUPTCY COURT TO ISSUE A SEARCH WARRANT}

In In re Trustee in Bankruptcy for Search Warrant to Undercover Property of Estate Held in Violation of 18 U.S.C. $\S 152,72$ the bankruptcy trustee sought the issuance of a search warrant to uncover assets allegedly belonging to the bankruptcy estate. ${ }^{73}$ The terse reported opinion does not provide any background facts, so it is unknown whether the trustee sought the search warrant to inspect the debtor's home. It is also unclear whether the bankruptcy trustee sought the warrant for purely civil purposes, namely, to locate assets in

${ }^{69} \mathrm{Id}$. at $369-70$.

${ }^{70}$ Id. at 372 (citing Taunt v. Barman (In re Barman), 252 B.R. 403, 416 (Bankr. E.D. Mich. 2000)).

${ }^{71}$ Id. at 372 (citing Barman, 252 B.R. at 416-17).

72173 B.R. 341 (N.D. Ohio 1994).

${ }^{73} \mathrm{Id}$. at 342 . Section 152 of the 18 U.S.C. makes it a bankruptcy crime for a debtor to knowingly and fraudulently conceal assets from a bankruptcy proceeding. 18 U.S.C. $\S 152$ (2006). 
the administration of the bankruptcy estate, or for the purpose of establishing the debtor's commission of a bankruptcy crime.

Nevertheless, the decision is instructive because in denying the trustee's request for a search warrant, the court relied upon Rule 41 of the Federal Rules of Criminal Procedure as its source of controlling authority. ${ }^{74}$ Rule 41(b) of the Federal Rules of Criminal Procedure provides that a search warrant may be issued only "[a]t the request of a federal law enforcement officer or an attorney for the government." 75 In turn, Rule 41(a)(2)(C) defines "[f]ederal law enforcement officer" to mean "a government agent (other than an attorney for the government) who is engaged in enforcing the criminal laws and is within any category of officers authorized by the Attorney General to request a search warrant." 76 While a bankruptcy trustee is a state actor for purposes of the Fourth Amendment, ${ }^{77}$ a bankruptcy trustee is neither a federal law enforcement officer nor an attorney for the government. Consequently, and correctly, the court declined to issue the search warrant pursuant to Rule 41 of the Federal Rules of Criminal Procedure.

In In re Skinner, ${ }^{78}$ the Chapter 7 trustee filed a motion for authority to enter the residence of a non-debtor party to search for assets allegedly belonging to the debtors' bankruptcy estate. ${ }^{79}$ Specifically, one of the debtors informed the trustee during the bankruptcy proceeding that he had hidden large sums of money in his former marital residence. ${ }^{80}$ Accordingly, the trustee requested permission to enter the former residence, in which the debtor no longer had any legal or equitable interest, in order to search for the hidden money. ${ }^{81}$ Relying upon the decision in In re Trustee in Bankruptcy for Search Warrant to Undercover Property of Estate Held in Violation of 18 U.S.C. $\$ 152$, the Skinner court denied the trustee's motion, concluding that a bankruptcy trustee has no authority to apply for a search warrant under Federal Rule of Criminal Procedure $41 . .^{82}$ In other words, the court in Skinner similarly relied upon Rule 41 of the Federal Rules of Criminal Procedure as the possible source of authority for a bankruptcy court to issue a search order of a debtor's home.

Finally, in Spacone v. Burke (In re Truck-A-Way), ${ }^{83}$ Hank Spacone was appointed as the Chapter 7 trustee to administer the assets of corporate debtor Truck-A-Way. ${ }^{84}$ The principal of Truck-A-Way, James Burke, had filed his

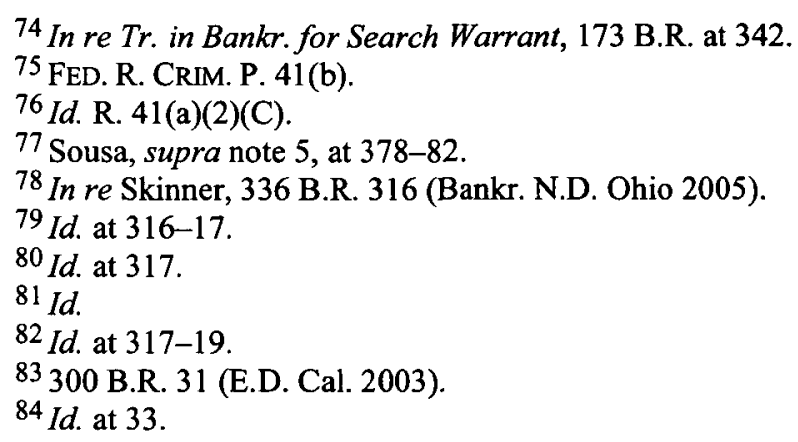


own separate personal bankruptcy petition. ${ }^{85}$ Counsel for the trustees for both the Truck-A-Way bankruptcy estate and the estate of James Burke filed an ex parte application for an order authorizing the entry into and search of residences owned by Burke in an effort to uncover property allegedly belonging to the bankruptcy estates..$^{86}$ The bankruptcy court granted the application. ${ }^{87}$ Because the trustees' subsequent conduct in executing the search seemingly exceeded the scope of the search and seizure order, Burke's wife filed a motion seeking to disqualify counsel for the Truck-A-Way bankruptcy estate. ${ }^{88}$

In the course of rendering its opinion on the motion to disqualify counsel, the court in Truck-A-Way addressed the propriety of a bankruptcy trustee searching a debtor's property under the Fourth Amendment. The court initially noted that any residence search would first require the attainment of a warrant. ${ }^{89}$ The court then held that any application for a search warrant cannot circumvent the requirements of the Fourth Amendment or Rule 41 of the Federal Rules of Criminal Procedure. ${ }^{90}$ That is, despite the recognized civil nature of the bankruptcy trustee's search, the court nonetheless concluded that the only avenue for a trustee to seek a search warrant is through Rule 41 of the Federal Rules of Criminal Procedure. ${ }^{91}$ Following prior precedent, the Truck-A-Way court held that a bankruptcy trustee has no authority to seek a warrant under Rule 41 because a trustee is "neither a federal 'law enforcement officer' nor 'an attorney for the government." 92 Significantly, the court added to its analysis by stating the following: "Clearly the explicit requirements of Rule 41 reflect the exacting mandate of the Fourth Amendment and cannot be circumvented by the statutory structure created by the Bankruptcy Code." 93

As will be explicated below, the reliance upon Federal Rule of Criminal Procedure 41 as the source of authority for a trustee to seek, and a court to issue, a search order for a debtor's residence is simply incorrect. However, the Federal All Writs Act and $\S 105$ of the Bankruptcy Code do provide the reasonable authority for a bankruptcy court to issue a search order.

\footnotetext{
${ }^{85} \mathrm{Id}$. at 33 n. 4 .

${ }^{86} \mathrm{Id}$. at 33 .

${ }^{87} \mathrm{Id}$.

${ }^{88} \mathrm{Id}$. at 35.
}

${ }^{89}$ Truck- $A$-Way, 300 B.R. at 35 ("Counsel employed ex parte procedures to obtain an order to search defendant's residences in Nevada and Southern California and seize property that he believed belonged to the bankruptcy estate. As he embarked on this effort, counsel never provided the bankruptcy court the statutory or caselaw authority, save reference to 11 U.S.C. §105(a), to support a warrantless search and seizure.").

90 Id. at 37 (E.D. Cal. 2003); see also United States v. Ventresca, 380 U.S. 102, 105 n.1 (1965) ("The Fourth Amendment's policy against unreasonable searches and seizures finds expression in Rule 41 of the Federal Rules of Criminal Procedure.").

91 Truck-A-Way, 300 B.R. at 36-37.

${ }^{92}$ Id. at 37 (quoting In re Tr. in Bankr. for Search Warrant to Undercover Prop. of Estate Held in Violation of 18 U.S.C. $\S 152,173$ B.R. 341, 342 (N.D. Ohio 1994)).

93 Id. at 38. 


\section{SOURCES OF AUTHORITY FOR A BANKRUPTCY COURT TO ISSUE A WARRANT TO SEARCH A DEBTOR'S RESIDENCE}

The existing case law in this area of bankruptcy jurisprudence is less than satisfactory for two reasons. First, the two courts that have issued a search warrant to a trustee have failed to articulate their source of authority for such an order. Second, the courts declining to issue a search warrant either question a bankruptcy court's ability to do so $^{94}$ or improperly rely upon Rule 41 of the Federal Rules of Criminal Procedure as the applicable source of authority to act.

Rule 1 of the Federal Rules of Criminal Procedure prescribes that the federal criminal procedure rules provide the substantial method of procedure "in all criminal proceedings" in the courts of the United States. ${ }^{95}$ As such, the issuance of a search warrant under Rule 41 of the Federal Rules of Criminal Procedure is necessarily limited to criminal proceedings. ${ }^{96}$ Because a bankruptcy proceeding is civil in nature, ${ }^{97}$ the Federal Rules of Criminal Procedure have no applicability, despite the reliance upon Rule 41 by the courts in Truck-A-Way, Skinner, and In re Trustee in Bankruptcy for Search Warrant to Undercover Property of Estate Held in Violation of 18 U.S.C. $\$ 152.98$

Furthermore, a bankruptcy trustee does not fall under the ambit of Rule 41 as an individual authorized to seek a warrant because a trustee is neither a federal law enforcement officer nor an attorney for the government. ${ }^{99}$ The vast majority of Chapter 7 trustees are accountants or attorneys engaged in private practice. ${ }^{100}$ In addition, Rule 41(c) of the Federal Rules of Criminal Procedure provides that a search warrant may be issued to uncover either "evidence of a crime," "contraband, fruits of crime, or other items illegally possessed,"

${ }^{94} \mathrm{Id}$. (noting strong disagreement with the Barman court's interpretation of its authority to act under the Fourth Amendment).

95 FED R. CRIM. P. 1(a)(1); Harrison v. United States, 191 F.2d 874, 875 (5th Cir. 1951).

${ }^{96}$ Amoco Tex. Ref. Co., No. H 80 79M, 1980 WL 29277, at *4 (S.D. Tex. June 13, 1980) ("The issuance of a search warrant under the Federal Rules of Criminal Procedure must necessarily be limited to criminal proceedings.").

${ }^{97}$ See Nat'l City Bank v. Flowers (In re Flowers), 83 B.R. 953, 954 (Bankr. N.D. Ohio 1988) ("A bankruptcy proceeding is civil in nature.").

${ }^{98}$ Cf. In re Farrar, CV. No. 07-00019 DAE-KSC, 2007 WL 601985, at*1 (D. Haw. Feb. 21, 2007) (noting that civil equitable proceedings do not permit reliance upon the Federal Rules of Criminal Procedure); James W. Fox, Jr., The Road Not Taken: Criminal Contempt Sanctions and Grand Jury Press Leaks, 25 U. MiCH. J.L. REFORM 505, 516-17 (1992) ("The choice between designating a contempt action as civil or criminal determines the procedural rules that govern the action. Civil contempt actions operate under the Federal Rules of Civil Procedure, while the Federal Rules of Criminal Procedure govern criminal contempt proceedings.").

${ }^{99}$ See United States v. McKeever, 905 F.2d 829, 833 (5th Cir. 1990) (holding that Rule 41 only applies to warrants issued at the request of federal officers).

${ }^{100}$ Sousa, supra note 5, at 380-81 n.96 ("The trustee is an attorney, as are most other Chapter 7 panel trustees." (citing In re Computer Learning Ctrs., Inc., 285 B.R. 191, 230 (Bankr. E.D. Va. 2002))). 
"property designed for use, intended for use, or used in committing a crime" or in order to arrest a person. ${ }^{101}$ Presumably, a bankruptcy trustee would seek to secure a search warrant for a debtor's home in order to uncover undisclosed assets belonging to the bankruptcy estate and potentially distributable to creditors in the course of administering the bankruptcy proceeding. Consequently, the purpose for which a search warrant is sought in the bankruptcy arena does not comport with the intended uses provided for by Rule 41 of the Federal Rules of Criminal Procedure.

However, complicating the observation that Rule 41 of the Federal Rules of Criminal Procedure does not apply to bankruptcy trustees is the fact that the intentional concealment of assets from the bankruptcy proceeding is at the same time both a civil violation of the Bankruptcy Code as well as a bankruptcy crime under federal law. ${ }^{102}$ Under $\S 727(a)(2)$ of the Bankruptcy Code, the

101 FED. R. CRIM. P. 41(c).

102 See Mary Jo Heston, The United States Trustee: The Missing Link of Bankruptcy Crime Prosecutions, 6 AM. BANKR. INST. L. REV. 359, 364 (1998) ("Civil fraud associated with bankruptcy cases often involves conduct that violates the related criminal provisions governing bankruptcy fraud."); see also Duggins v. Heffron, 128 F.2d 546, 548 (9th Cir. 1942) ("Not only was there this concealment in the year prior to the bankruptcy, but the bankrupt failed to state his equitable ownership in his schedules. Such an omission in the schedules constituting concealment may also constitute a false oath, both punishable by imprisonment under the Bankruptcy Act, if the omission is false and intentional." (footnote omitted)). The federal bankruptcy crimes are contained in 18 U.S.C. $\S \S 152-157$ (2006). Most relevant for present purposes is 18 U.S.C. $\S 152$, which provides as follows:

A person who-

(1) knowingly and fraudulently conceals from a custodian, trustee, marshal, or other officer of the court charged with the control or custody of property, or, in connection with a case under title 11, from creditors or the United States Trustee, any property belonging to the estate of a debtor;

(2) knowingly and fraudulently makes a false oath or account in or in relation to any case under title 11 ;

(3) knowingly and fraudulently makes a false declaration, certificate, verification, or statement under penalty of perjury as permitted under section 1746 of title 28 , in or in relation to any case under title 11 ;

(4) knowingly and fraudulently presents any false claim for proof against the estate of a debtor, or uses any such claim in any case under title 11, in a personal capacity or as or through an agent, proxy, or attorney;

(5) knowingly and fraudulently receives any material amount of property from a debtor after the filing of a case under title 11, with intent to defeat the provisions of title 11;

(6) knowingly and fraudulently gives, offers, receives, or attempts to obtain any money or property, remuneration, compensation, reward, advantage, or promise thereof for acting or forbearing to act in any case under title 11;

(7) in a personal capacity or as an agent or officer of any person or corporation, in contemplation of a case under title 11 by or against the person or any other person or corporation, or with intent to defeat the provisions of title 11 , knowingly and fraudulently transfers or conceals any of his property or the property of such other person or corporation; 
discharge of a Chapter 7 debtor may be withheld if the debtor intentionally conceals property from creditors either within the one-year period preceding bankruptcy or at some time after the petition is filed. ${ }^{103}$ At the same time, a debtor commits a bankruptcy crime under 18 U.S.C. $\S 152$ if he or she "knowingly and fraudulently" conceals from a trustee "any property belonging to the estate of a debtor." 104 If found guilty of criminal concealment, a debtor is subject to fines or imprisonment. ${ }^{105}$ Nonetheless, the potential for such conduct to constitute a crime would not invalidate the propriety of a civil search, because the Supreme Court has held that a valid administrative search will not be subsequently found unconstitutional simply because the search may uncover violations of both civil and criminal laws. ${ }^{106}$

The statutory duties of a bankruptcy trustee are enumerated in $\S \S 704$ and 1302 of the Bankruptcy Code. ${ }^{107}$ In general, a bankruptcy trustee gathers and

(8) after the filing of a case under title 11 or in contemplation thereof, knowingly and fraudulently conceals, destroys, mutilates, falsifies, or makes a false entry in any recorded information (including books, documents, records, and papers) relating to the property or financial affairs of a debtor; or

(9) after the filing of a case under title 11, knowingly and fraudulently withholds from a custodian, trustee, marshal, or other officer of the court or a United States Trustee entitled to its possession, any recorded information (including books, documents, records, and papers) relating to the property or financial affairs of a debtor,

shall be fined under this title, imprisoned not more than 5 years, or both.

18 U.S.C. $\$ 152$ (2006). For a discussion of federal bankruptcy crimes, see generally Heston, supra, at 359, Tamara Ogier \& Jack F. Williams, Bankruptcy Crimes and Bankruptcy Practice, 6 AM. BANKR. INST. L. REV. 317 (1998), and Maureen A. Tighe, A Guide to Making a Criminal Bankruptcy Fraud Referral, 6 AM. BANKR. INST. L. REV. 409 (1998).

${ }^{103}$ Section 727(a)(2) of the Bankruptcy Code provides as follows:

(a) The court shall grant the debtor a discharge, unless-

…

(2) the debtor, with intent to hinder, delay, or defraud a creditor or an officer of the estate charged with custody of property under this title, has transferred, removed, destroyed, mutilated, or concealed, or has permitted to be transferred, removed, destroyed, mutilated, or concealed-

(A) property of the debtor, within one year before the date of the filing of the petition; or

(B) property of the estate, after the date of the filing of the petition....

11 U.S.C. $\S 727(a)(2)$.

10418 id. $\S 152(1)$.

$105 \mathrm{Id}$ § 152 .

${ }^{106}$ Tracey Maclin, Is Obtaining an Arrestee's DNA a Valid Special Needs Search Under the Fourth Amendment? What Should (and Will) the Supreme Court Do?, J.L. MED. \& ETHICS, Spring 2005, at 102, 117 (citing New York v. Burger, 482 U.S. 691, 712 (1987)).

${ }^{107}$ In a Chapter 7 case, a bankruptcy trustee is responsible for the following actions:

(a) The trustee shall- 
liquidates the property of the estate distributable to creditors, ensures that the debtor performs her statutory obligations, and investigates the financial affairs of the debtor. ${ }^{108}$ And while a private bankruptcy trustee is charged with ensuring compliance with the Bankruptcy Code, she is not charged with the responsibility of investigating the possible commission of bankruptcy crimes by debtors. ${ }^{109}$ Rather, when it appears that a debtor is abusing the bankruptcy system, a trustee must either make a referral to the U.S. Trustee or to the regional office of the U.S. Attorney. ${ }^{110}$

Indeed, 18 U.S.C. $\S 3057$ (a) specifically contemplates that if a trustee has "reasonable grounds" for believing that a bankruptcy crime under 18 U.S.C. $\S 152$ has been committed and that an investigation is warranted, the trustee "shall report to the appropriate United States attorney all the facts and

(1) collect and reduce to money the property of the estate for which such trustee serves, and close such estate as expeditiously as is compatible with the best interests of parties in interest;

(2) be accountable for all property received;

(3) ensure that the debtor shall perform his intention as specified in section

$521(\mathrm{a})(2)(\mathrm{B})$ of this title;

(4) investigate the financial affairs of the debtor;

(5) if a purpose would be served, examine proofs of claims and object to the allowance of any claim that is improper;

(6) if advisable, oppose the discharge of the debtor;

(7) unless the court orders otherwise, furnish such information concerning the estate and the estate's administration as is requested by a party in interest;

(8) if the business of the debtor is authorized to be operated, file with the court, with the United States trustee, and with any governmental unit charged with responsibility for collection or determination of any tax arising out of such operation, periodic reports and summaries of the operation of such business, including a statement of receipts and disbursements, and such other information as the United States trustee or the court requires; [and]

(9) make a final report and file a final account of the administration of the estate with the court and with the United States trustee....

11 U.S.C. $\S 704(a)(1)-(9)$. A Chapter 13 standing trustee has many of the same responsibilities as her Chapter 7 counterpart. See id. $\S 1302(b)(1)$ (providing that a Chapter 13 trustee has some of the same duties as a Chapter 7 trustee pursuant to $\S 704$ of the Bankruptcy Code).

${ }^{108}$ Curry v. Castillo (In re Castillo), 297 F.3d 940, 950 (9th Cir. 2002).

${ }^{109} 28$ U.S.C. $\$ 586(\mathrm{a})(3)(\mathrm{F})$ specifically directs the U.S. Trustee to notify the appropriate U.S. Attorney of suspected banknuptcy crimes. Id. $\S 586(\mathrm{a})(3)(\mathrm{F})$; see also Heston, supra note 102, at 397 (noting that the U.S. Trustee serves as the "initiator of criminal referrals").

110 Neil C. Gordon, Federal Crimes: The Trustee's Role, AM. BANKR. INST. J., Dec./Jan. 2010 , at 52,52 ("Trustees are generally directed by their U.S. Trustee to make referrals to that office, but in certain districts, the referral is made directly to the U.S. Attorney."); see also Kirk v. Hendon (In re Heinsohn), 231 B.R. 48, 59 (Bankr. E.D. Tenn. 1999) ("A trustee has a statutory duty under 18 U.S.C. $\S 3057$ to notify the United States attorney and report all of the relevant facts and circumstances of the case if he believes that a crime has been committed or that further investigation is appropriate."). 
circumstances of the case, the names of the witnesses and the offense or offenses believed to have been committed."111 If such a referral is made, it is then incumbent upon the U.S. Attorney's Office, and not the private case trustee, to investigate the allegations, report to the bankruptcy court, and seek an indictment, if warranted. ${ }^{112}$ Consequently, so long as the private trustee is not undertaking her own criminal investigation and searching for evidence of the bankruptcy crime of concealing assets, then Rule 41 of the Federal Rules of Criminal Procedure should not be relied upon by courts as potential authority to issue a search warrant to a bankruptcy trustee. The inapplicability of Rule 41 of the Federal Rules of Criminal Procedure does not render the issuance of a warrant by a bankruptcy court impossible, because Rule 41(a) specifically contemplates that Rule 41 "does not modify any statute regulating search or seizure" or control "the issuance and execution of a search warrant in special circumstances." 113 In other words, to the extent a search warrant can be issued pursuant to another source of authority, Rule 41(a) serves to preserve, and not supersede, this secondary procedure.

If Rule 41 of the Federal Rules of Criminal Procedure does not provide the requisite authority for a trustee to seek a search warrant in the civil bankruptcy context, the question remains whether any source does in fact permit such a remedy. Because at present the Bankruptcy Code does not statutorily authorize a search of a debtor's home, resort to another federal statute is necessary. In this regard, it is possible that a bankruptcy court may issue a search warrant by relying upon the Federal All Writs Act or $\S 105$ of the Bankruptcy Code.

\section{A. The Federal All Writs Act as a Source of Statutory Authority}

The Federal All Writs Act, codified by 28 U.S.C. $\S 1651$, provides as follows: "The Supreme Court and all courts established by Act of Congress may issue all writs necessary or appropriate in aid of their respective jurisdictions and agreeable to the usages and principles of law." 114 Section 14 of the

11118 U.S.C. $\S 3057$ (a).

112 See id. $\S 3057$ (b) ("The United States attorney thereupon shall inquire into the facts and report thereon to the judge, and if it appears probable that any such offense has been committed, shall without delay, present the matter to the grand jury, unless upon inquiry and examination he decides that the ends of public justice do not require investigation or prosecution, in which case he shall report the facts to the Attorney General for his direction.").

113 FED. R. CRIM P. 41(a). It has been held that Rule 41(a) "preserves all statutory provisions permitting searches in specific situations not otherwise explicitly set forth in the rule." Amoco Oil Co. v. Marshall, 496 F. Supp. 1234, 1239 (S.D. Tex. 1980) (citing Marshall v. Huffhines Steel Co., 478 F. Supp. 986, 989 (N.D. Tex. 1979)); cf. Gooding v. United States, 416 U.S. 430, 439 (1974) (holding that Rule 41 of the Federal Rules of Criminal Procedure is not applicable to searches governed by specific narcotics search statutes).

11428 U.S.C. $\S 1651$ (a). "The statutory ancestors of $\S 1651$ (a) are sections 13 and 14 of the Judiciary Act of 1789 ...." Lonny Sheinkopf Hoffman, Removal Jurisdiction and the 
Judiciary Act of 1789 , the direct historical ancestor to the All Writs Act, has been described as the "most expansive and open-ended" provision of the Judiciary Act itself. 115 As understood by Professor Wythe Holt, writs issued pursuant to Section 14 of the Judiciary Act could be employed to address matters of "great moment," since the writs were often "broad and relatively open-ended." 116 As interpreted by the Supreme Court, the All Writs Act allows a federal court to " avail itself of all auxiliary writs as aids in the performance of its duties, when the use of such historic aids is calculated in its sound judgment to achieve the ends of justice entrusted to it." 117 Indeed, the All Writs Act serves as a "legislatively approved source of procedural instruments designed to achieve "the rational ends of law."'18 As contemplated by the Supreme Court, the All Writs Act enables courts to "fashion extraordinary remedies when the need arises." 119 Lower federal courts interpret the All Writs Act as providing them with "wide latitude...t to construct any remedy necessary to 'achieve justice."' 120

However, the power of a court to issue an order under the All Writs Act is not without limitation. As interpreted today, the All Writs Act does not create any substantive federal jurisdiction. ${ }^{121}$ Rather, the All Writs Act enables courts to issue writs in aid of jurisdiction already acquired on some other independent basis. ${ }^{122}$ Once jurisdiction is vested in a federal court on an independent basis,

All Writs Act, 148 U. PA. L. REV. 401, 433 (1999). Sections 13 and 14 of the Judiciary Act of 1789 were subsequently consolidated into the All Writs Act in 1948. Fruqan Mouzon, Forgive Us Our Trespasses: The Need for Federal Expungement Legislation, 39 U. MEM. L. REV. 1, $15 \mathrm{n} .50$ (2008). Section 13 of the Judiciary Act of 1789 provided in relevant part that the Supreme Court shall have the "power to issue writs of prohibition ... [or] mandamus in cases warranted by the principles and usages of law." Judiciary Act of 1789, ch. 20, $\S 13,1$ Stat. 73, 80-81 (footnote omitted). In turn, Section 14 of the Judiciary Act of 1789 provided as follows: "[A]ll the before-mentioned courts of the United States, shall have power to issue writs of scire facias, habeas corpus, and all other writs not specially provided for by statute, which may be necessary for the exercise of their respective jurisdictions, and agreeable to the principles and usages of law." Id. $\S 14,1$ Stat. at 81-82 (footnote omitted). For a historical account of the enactment of the Federal Judiciary Act of 1789, see generally Charles Warren, New Light on the History of the Federal Judiciary Act of 1789, 37 HARV. L. REV. 49 (1923).

115 Wythe Holt, "To Establish Justice": Politics, the Judiciary Act of 1789, and the Invention of the Federal Courts, 1989 DUKE L.J. 1421, 1507.

${ }^{116} I d$.

${ }^{117}$ United States v. N.Y. Tel. Co., 434 U.S. 159, 173 (1977) (quoting Adams v. United States ex rel. McCann, 317 U.S. 269, 273 (1942)).

118 Price v. Johnston, 334 U.S. 266, 282 (1942) (citation omitted); see also N.Y. Tel. Co., 434 U.S. at 172 (stating same).

${ }^{119}$ Pa. Bureau of Corr. v. U.S. Marshals Serv., 474 U.S. 34, 43 (1985).

120 United States v. Javanmard, 767 F. Supp. 1109, 1111 (D. Kan. 1991).

121 Klay v. United Healthgroup, Inc., 376 F.3d 1092, 1099 (11 th Cir. 2004).

122 Brittingham v. Comm'r, 451 F.2d 315, 317 (5th Cir. 1971); see also Telecomms. Research \& Action Ctr. v. FCC, 750 F.2d 70, 77 (D.C. Cir. 1984) (holding same); United States v. Hall, 583 F. Supp. 717, 718 (E.D. Va. 1984) ("The statute is in no way 
however, the All Writs Act "empowers that court to enter such orders as it deems necessary, in its discretion, to preserve and protect its jurisdiction."123 The All Writs Act is a "residual source of authority" for courts to issue writs that are not otherwise provided for by another statute. ${ }^{124}$ Where a statute specifically addresses the particular issue under consideration by a court, it is this other statute, and not the All Writs Act, that is controlling. ${ }^{125}$ Accordingly, the All Writs Act serves as a gap filler to existing law where the latter is silent on the specific issue before the court. ${ }^{126}$ Finally, the All Writs Act does not authorize courts to issue ad hoc writs to circumvent otherwise applicable, but perhaps more burdensome, statutory procedures. ${ }^{127}$

The purpose and function of the All Writs Act is to supply the federal courts with the mechanisms and instruments needed to perform their duty, as prescribed by Congress and the Constitution. ${ }^{128}$ That said, however, it has been noted that "the Supreme Court's efforts to construe the All Writs Act have failed to define clearly the Act's grant of power."129 Nevertheless, certain prerequisites must exist before a court will issue an order under the All Writs Act. ${ }^{130}$ First, there must be "an absence of alternative remedies." 131 If the matter

jurisdictional; it neither enlarges nor expands jurisdiction of the court; it may be invoked only to aid jurisdiction which the Court already has.").

${ }^{123}$ In re Order Authorizing the Use of a Pen Register, 538 F.2d 956, 961 (2d Cir. 1976), rev'd on other grounds sub nom. N.Y. Tel. Co., 434 U.S. at 172.

${ }^{124} \mathrm{~Pa}$. Bureau of Corr., 474 U.S. at 43.

125 Id.

${ }^{126}$ Dimitri D. Portnoi, Note, Resorting to Extraordinary Writs: How the All Writs Act Rises to Fill the Gaps in the Rights of Enemy Combatants, 83 N.Y.U. L. REV. 293, 298 (2008).

${ }^{127} \mathrm{~Pa}$. Bureau of Corr., 474 U.S. at 43 ("Although [the All Writs] Act empowers federal courts to fashion extraordinary remedies when the need arises, it does not authorize them to issue ad hoc writs whenever compliance with statutory procedures appears inconvenient or less appropriate.").

${ }^{128}$ Harris v. Nelson, 394 U.S. 286, 300 (1969).

129 Daniel J. Wacker, The "Unreviewable" Court-Martial Conviction: Supervisory Relief Under the All Writs Act from the United States Court of Military Appeals, 10 HARV. C.R.-C.L. L. REV. 33, 58 (1975).

${ }^{130}$ Notably, the issuance of an injunction under the All Writs Act need not comply with the requirements for a traditional injunction. Klay v. United Healthgroup, Inc., 376 F.3d 1092, 1100 (11th Cir. 2004); Liberty Mut. Ins. Co. v. Aventura Eng'g \& Constr. Corp., 534 F. Supp. 2d 1290, 1324 (S.D. Fla. 2008) ("When considering whether to grant an All Writs Injunction, the [c]ourt does not review the four factors required for a traditional injunction."). The requirements for a traditional injunction generally are as follows:

(1) the likelihood of the moving party's success on the merits; (2) the possibility of irreparable injury to the moving party if relief is not granted; (3) the extent to which the balance of hardships favors the respective parties; and (4) in certain cases, whether the public interest will be advanced by granting the preliminary relief.

Owner-Operator Indep. Drivers Ass'n v. Swift Transp. Co., 367 F.3d 1108, 1111 (9th Cir. 2004) (quoting Miller ex rel. NLRB v. Cal. Pac. Med. Ctr., 19 F.3d 449, 456 (9th Cir. 1994)) (internal quotation marks omitted). 
before the court is addressed in a particular statute, then the All Writs Act has no place. ${ }^{132}$ Second, as noted above, because the All Writs Act does not confer jurisdiction upon a federal court, there must exist "an independent basis for jurisdiction" prior to any reliance upon the All Writs Act. ${ }^{133}$ Third, an order must be exercised only "in aid of" a federal court's jurisdiction. ${ }^{134}$ While this language is not defined by the statute, courts have construed it to mean that the offending behavior, if left unchecked, would undermine or be detrimental to the court's independent jurisdiction over the pending matter ${ }^{135}$ or inhibit a court's efforts to manage a case to judgment. ${ }^{136}$ As a corollary to this notion, the All Writs Act has been utilized by federal courts in issuing orders appropriate to assist them in undertaking factual inquiries. ${ }^{137}$ Fourth, an order entered under the All Writs Act must be "agreeable to the usages and principles of law."138 This provision is also undefined by the Act; however, at least one court has interpreted this language to mean that any order under the Act must not offend established principles relative to the particular writ sought. ${ }^{139}$

Bankruptcy courts are "courts established by Act of Congress" 140 and, thus, have the ability to utilize the All Writs Act in fashioning appropriate orders. ${ }^{141}$

131 Portnoi, supra note 126, at 299.

${ }^{132} \mathrm{~Pa}$. Bureau of Corr., 474 U.S. at 43; see also Clinton v. Goldsmith, 526 U.S. 529, 537 (1999) ("The All Writs Act invests a court with a power essentially equitable and, as such, not generally available to provide alternatives to other, adequate remedies at law." (citing Carlisle v. United States, 517 U.S. 416, 429 (1996))).

133 Portnoi, supra note 126 , at 301.

134 Id. at 302 .

${ }^{135}$ Klay, 376 F.3d at 1110 ; ITT Cmty. Dev. Corp. v. Barton, 569 F.2d 1351, 1359 (5th Cir. 1978); cf. Pa. Bureau of Corr., 474 U.S. at 41 ("Our early view of the scope of the all writs provision confined it to filling the interstices of federal judicial power when those gaps threatened to thwart the otherwise proper exercise of federal courts' jurisdiction.").

${ }^{136}$ ITT Cmty. Dev. Corp. v. Barton, 457 F. Supp. 224, 232 (M.D. Fla. 1978).

${ }^{137}$ See, e.g., Am. Lithographic Co. v. Werckmeister, 221 U.S. 603, 609 (1911) (subpoenas duces tecum); Bethlehem Shipbuilding. Corp. v. NLRB, 120 F.2d 126, 127 (1st Cir. 1941) (ordering that certain documents be produced for the purpose of pretrial discovery).

13828 U.S.C. $\S 1651$ (a) (2006).

${ }^{139}$ Paramount Film Distrib. Corp. v. Civic Ctr. Theatre, Inc., 333 F.2d 358, 360 (10th Cir. 1964).

140 Goodman v. Cal. Portland Cement Co. (In re GTI Capital Holdings, LLC), 420 B.R. 1, 11 (Bankr. D. Ariz. 2009).

141 Penn Cent. Transp. Co. v. Irving Trust Co., 594 F.2d 952, 957 (3d Cir. 1979) (recognizing the ability of a bankruptcy court to rely upon the Federal All Writs Act). Congress created bankruptcy courts under Title 28 of the U.S. Code. In essence, bankruptcy courts constitute "units" or "adjuncts" of the corresponding district courts. King v. Florida (In re King), 280 B.R. 767, 777 (Bankr. S.D. Ga. 2002). In particular, 28 U.S.C. $\S 151$ provides as follows:

In each judicial district, the bankruptcy judges in regular active service shall constitute a unit of the district court to be known as the bankruptcy court for that district. Each bankruptcy judge, as a judicial officer of the district court, may exercise the authority 
Bankruptcy courts have relied upon the All Writs Act as a source of authority to issue orders in several different circumstances, including: (1) restricting the filing of vexatious cases or pleadings; ${ }^{142}$ (2) precluding the initiation of any lawsuits by defendants in an adversary proceeding against the debtors or their post-confirmation trust; ${ }^{143}$ and (3) staying payments to beneficiaries from a personal injury settlement trust. ${ }^{144}$ To date, no reported decision has contemplated the use of the All Writs Act as a source of authority for a bankruptcy court to issue an order to search a debtor's home upon suspicion of concealing assets. But this absence does not mean that a federal court is lacking such authority.

The prerequisites for the issuance of an order under the All Writs Act are met in the context of a bankruptcy trustee seeking an administrative search order for a debtor's home in carrying out her duty to investigate the financial affairs of a debtor. Because the Bankruptcy Code does not currently provide for the issuance of an administrative search warrant and Federal Rule of Criminal Procedure 41 does not apply in the bankruptcy context, an alternative remedy does not exist whereby a trustee can obtain relief to search a debtor's home upon adequate suspicion of fraud. Furthermore, a bankruptcy trustee would not be relying upon the All Writs Act to confer jurisdiction upon the bankruptcy court. Jurisdiction would already be conferred upon the court by 28 U.S.C. $\S 1334^{145}$ and 28 U.S.C. $\S 157\left(\right.$ a). ${ }^{146}$ The failure to issue an administrative search order upon suspicion of debtor fraud undermines both the integrity of the bankruptcy process itself and the obligation of debtors to be fully forthcoming in their disclosures to the court, in exchange for the benefits conferred by bankruptcy law, most notably the discharge of pre-petition debt. ${ }^{147}$ In terms of the All Writs Act, "the jurisdiction being 'aided' here is that of the bankruptcy court and its administration and protection of the bankruptcy estate."148 The

conferred under this chapter with respect to any action, suit, or proceeding and may preside alone and hold a regular or special session of the court, except as otherwise provided by law or by rule or order of the district court.

28 U.S.C. $\S 151$.

142 Armstrong v. Rushton (In re Armstrong), 309 B.R. 799, 805, 807-10 (B.A.P. 10th Cir. 2004); Teachers Ins. \& Annuity Ass'n of Am. v. Butler, 58 B.R. 1019, 1022 (S.D.N.Y. 1986); Stanwyck v. Bogen (In re Stanwyck), 450 B.R. 181, 200, 206 (Bankr. C.D. Cal. 2011); Goodman, 420 B.R. at 11-12, 15-16.

143 Post-Confirmation Trust v. Berry (In re Fleming Cos.), 444 B.R. 127, 136 (Bankr. D. Del. 2011).

${ }^{144}$ Findley v. Laughead (In re Johns-Manville Corp.), 27 F.3d 48, 49 (2d Cir. 1994).

145 Section 1334(a) of 28 U.S.C. confers original jurisdiction in the district courts over all bankruptcy cases. 28 U.S.C. $\$ 1334($ a).

${ }^{146}$ Section 157 (a) of 28 U.S.C. provides that the district courts may refer all bankruptcy cases and related proceedings to the bankruptcy courts. Id. $\$ 157$ (a).

${ }^{147}$ Roudebush v. Sharp (In re Sharp), 244 B.R. 889, 891 (Bankr. E.D. Mich. 2000).

148 See Post-Confirmation Trust, 444 B.R. at 138 (noting that the issuance of an injunction by the bankruptcy court under the All Writs Act to prevent suits against the 
most complex aspect of applying the All Writs Act to authorize a search of a debtor's home is with the statute's requirement that any order be "agreeable to the usages and principles of law." 149 Although this standard remains undefined, it is reasonable to presume that any search order issued pursuant to the All Writs Act should comply with established principles in a related area of law, namely Fourth Amendment jurisprudence.

The Fourth Amendment to the U.S. Constitution applies in both the criminal and civil contexts. ${ }^{150}$ Consequently, any search of a debtor's home must comply with Fourth Amendment principles, even though Federal Rule of Criminal Procedure 41 does not apply in the bankruptcy arena. Historically, the indiscriminate and suspicionless searches and seizures carried out by British officials under the authority of the infamous writs of assistance "were the immediate evils that motivated the framing and adoption of the Fourth Amendment."151 Because the execution of the writs of assistance enabled British officials to search an individual's home without restraint, the concern for privacy in the home has been described as "the root of the Fourth Amendment itself."152 Indeed, the U.S. Supreme Court has consistently recognized a special

debtors or their post-confirmation trust would serve to protect the estate and its continued administration).

14928 U.S.C. $\S 1651$.

${ }^{150}$ Soldal v. Cook Cnty., 506 U.S. 56, 67 (1992); see also McCabe v. Life-Line Ambulance Serv., Inc., 77 F.3d 540, 544 (1st Cir. 1996) ("The Fourth Amendment applies not only to governmental searches and seizures in criminal investigations, but also in various civil proceedings."). "The purpose of the Fourth Amendment is to protect citizens against unnecessary intrusions into their privacy." United States v. Hanon, 428 F.2d 101, 104 (8th Cir. 1970) (citing Berger v. New York, 388 U.S. 41, 59 (1967)).

151 Payton v. New York, 445 U.S. 573, 583 (1980); see also Stone v. Powell, 428 U.S. 465,482 (1976) ("The Amendment was primarily a reaction to the evils associated with the use of the general warrant in England and the writs of assistance in the Colonies ...."); Boyd v. United States, 116 U.S. 616, 641 (1886) (Miller, J., concurring) ("While the framers of the Constitution had their attention drawn, no doubt, to the abuses of this power of searching private houses and seizing private papers, as practiced in England, it is obvious that they only intended to restrain the abuse, while they did not abolish the power."). For a detailed historical account of the writs of assistance and the resistance thereto by the American colonists, see generally Akhil Reed Amar, The Fourth Amendment, Boston, and the Writs of Assistance, 30 SUFFOLK U. L. REV. 53 (1996) [hereinafter Amar, Writs of Assistance], Akhil Reed Amar, Fourth Amendment First Principles, 107 HARV. L. REV. 757 (1994), Thomas K. Clancy, The Fourth Amendment's Concept of Reasonableness, 2004 UTAH L. REv. 977, Geoffrey G. Hemphill, The Administrative Search Doctrine: Isn't This Exactly What the Framers Were Trying to Avoid?, 5 REGENT U. L. REV. 215 (1995), Tracey Maclin, The Complexity of the Fourth Amendment: A Historical Review, 77 B.U. L. REV. 925 (1997) [hereinafter Maclin, The Complexity of the Fourth Amendment], Tracey Maclin, Let Sleeping Dogs Lie: Why the Supreme Court Should Leave Fourth Amendment History Unabridged, 82 B.U. L. REV. 895 (2002) [hereinafter Maclin, Let Sleeping Dogs Lie], and David E. Steinberg, The Original Understanding of Unreasonable Searches and Seizures, 56 FLA. L. REV. 1051 (2004).

${ }^{152}$ Craig M. Bradley, "Knock and Talk" and the Fourth Amendment, 84 IND. L.J. 1099, 1101 (2009). As Professor Tracey Maclin explains: 
privacy protection for intrusions into the home. ${ }^{153}$ The Court in Payton $v$. New York expressed this sentiment in unmistakable terms: "The Fourth Amendment protects the individual's privacy in a variety of settings. In none is the zone of privacy more clearly defined than when bounded by the unambiguous physical dimensions of an individual's home ...."154

Given the traditional protection against governmental intrusions into the home, a warrantless search of a residence is presumptively unreasonable unless some limited exception applies. ${ }^{155}$ Many of these exceptions, such as police rendering emergency aid, ${ }^{156}$ pursuing a fleeing felon, ${ }^{157}$ or preventing the destruction of evidence ${ }^{158}$ obviously do not apply in the bankruptcy context. More particularly in the administrative context, a warrantless search of a residence has been upheld only in the case of exigent circumstances ${ }^{159}$ or "special needs," whereby a government intrusion serves needs beyond those of normal law enforcement and crime detection. 160 To date, the "special needs"

Protecting the security of private homes was certainly a priority for the Framers. Indeed, one could say that the Framers were particularly sensitive about safeguarding private homes from governmental intrusion, as the constitutional privilege against unreasonable search and seizure "arose from the harsh experience of householders having their doors hammered open by magistrates and writ-bearing agents of the crown. Indeed, the Fourth Amendment is explainable only by the history and memory of such abuse." The intrusions that the colonists experienced at the hands of British customs officers "had done violence to the ancient maxim that "A man's house is his castle."

Maclin, Let Sleeping Dogs Lie, supra note 151, at 933 (footnote omitted).

${ }^{153}$ Griffin v. Wisconsin, 483 U.S. 868, 884 (1987) (Blackmun, J., dissenting).

154 Payton, 445 U.S. at 589; see also Kyllo v. United States, 533 U.S. 27, 31 (2001); Silverman v. United States, 365 U.S. 505, 511 (1961) ("The Fourth Amendment, and the personal rights which it secures, have a long history. At the very core stands the right of a man to retreat into his own home and there be free from unreasonable governmental intrusion."). In order to claim the protection of the Fourth Amendment against unwarranted intrusions, an individual must satisfy the two-part test enunciated by Justice Harlan in Katz $v$. United States. First, the individual must exhibit an actual subjective expectation of privacy, and second, this expectation of privacy must be one that society is prepared to recognize as reasonable. Katz v. United States, 389 U.S. 347, 361 (1967) (Harlan, J., concurring).

155 Kentucky v. King, 131 S. Ct. 1849, 1856 (2011); see also Donovan v. Dewey, 452 U.S. 594, 598 (1981) (noting that searches of private homes generally must be conducted pursuant to a warrant); United States v. Harrison, 639 F.3d 1273, 1278 (10th Cir. 2011) (“A warrantless search of a home is presumptively unreasonable ... ."); Lesser v. Espy, 34 F.3d 1301, 1305 ( 7 th Cir. 1994) (noting that a search of a private residence generally must be conducted pursuant to a warrant in order to be reasonable (citing Payton, 445 U.S. at 586)).

${ }^{156}$ Brigham City v. Stuart, 547 U.S. 398, 403 (2006).

157 United States v. Santana, 427 U.S. 38, 42-43 (1976).

158 Minnesota v. Olson, 495 U.S. 91,100 (1990).

159 Anobile v. Pelligrino, 303 F.3d 107, 120 (2d Cir. 2002).

${ }^{160}$ For articles addressing the "special needs" exception to the Fourth Amendment, see generally Fabio Arcila, Jr., Special Needs and Special Deference: Suspicionless Civil Searches in the Modern Regulatory State, 56 ADMIN. L. REV. 1223 (2004); George M. Dery 
doctrine has been limited to administrative residence searches of probationers or parolees. ${ }^{161}$ As recognized by the U.S. District Court for the Southern District of New York in United States v. Kone, warrantless searches of probationers' and parolees' homes have been approved by the Supreme Court "in situations where a governing statute, regulation, or condition of parole authorized the warrantless search."162 The doctrine has never been applied to the bankruptcy context, and as previously noted, the Bankruptcy Code does not authorize or contemplate a search of a debtor's home. Thus, despite my contentions in a prior article that the special needs exception can apply in bankruptcy, ${ }^{163}$ it is uncertain whether a court would ever accept such a departure from the Fourth Amendment's warrant requirement.

Ultimately, a bankruptcy trustee's conduct must be reasonable in order to comply with the Fourth Amendment. ${ }^{164}$ The reasonableness of the search will be determined by balancing the degree to which it intrudes upon the individual's privacy against the degree to which the search is needed to promote legitimate governmental interests. ${ }^{165}$ As a result of the heightened protection afforded to the home under the Fourth Amendment, a bankruptcy trustee would need to seek a search order from the court prior to conducting any search for undisclosed assets. ${ }^{166}$ Because a search order issued pursuant to the All Writs Act must not offend the Fourth Amendment, some protections in obtaining a search warrant should carry over into the bankruptcy context. That is, any

III, Are Politicians More Deserving of Privacy than Schoolchildren? How Chandler v. Miller Exposed the Absurdities of Fourth Amendment "Special Needs" Balancing, 40 ARIZ. L. REV. 73 (1998); Kenneth Nuger, The Special Needs Rationale: Creating a Chasm in Fourth Amendment Analysis, 32 SANTA ClARA L. REV. 89 (1992); Sousa, supra note 5; Jennifer Y. Buffaloe, Note, "Special Needs" and the Fourth Amendment: An Exception Poised to Swallow the Warrant Preference Rule, 32 HARV. C.R.-C.L. L. REV. 529 (1997).

${ }^{161}$ See, e.g., Samson v. Califormia, 547 U.S. 843, 857 (2006) (search of a parolee's residence); Griffin v. Wisconsin, 483 U.S. 868, 873-74 (1987) (search of probationer's home).

162 United States v. Kone, 591 F. Supp. 2d 593, 601 (S.D.N.Y. 2008).

163 See Sousa, supra note 5, at 367.

${ }^{164}$ Kentucky v. King, 131 S. Ct. 1849, 1856 (2011) (quoting Brigham City v. Stuart, 547 U.S. 398, 403 (2006)); see also Camara v. Mun. Court, 387 U.S. 523, 539 (1967) (noting that reasonableness is the "ultimate standard" under the Fourth Amendment).

165 United States v. Knights, 534 U.S. 112, 118-19 (2001); see also Bd. of Educ. v. Earls, 536 U.S. $822,829(2002)$ ("It is true that we generally determine the reasonableness of a search by balancing the nature of the intrusion on the individual's privacy against the promotion of legitimate governmental interests." (citing Delaware v. Prouse, 440 U.S. 648, 654 (1979))); Terry v. Ohio, 392 U.S. 1, 21 (1968) ("[F]or there is "no ready test for determining reasonableness other than by balancing the need to search .... against the invasion which the search ... entails." (quoting Camara, 387 U.S. at 536-37)).

${ }^{166}$ Searches conducted pursuant to a valid warrant are presumptively reasonable; however, the execution of the search must still be reasonable. United States v. Goldenberg, No. 05 CR. 1034(DC), 2006 WL 266564, at *2 (S.D.N.Y. Feb. 3, 2006). 
search order should be issued by a neutral and detached bankruptcy judge. 167 The application for a search order may be made ex parte to the court, ${ }^{168}$ but only under circumstances where the trustee has reasonable grounds to believe that the debtor is actively concealing assets in the home and would likely dispose of the assets if prior notice is provided.169 Though a showing of probable cause is not specifically required to obtain a warrant in the civil context, ${ }^{170}$ the bankruptcy trustee still must present the facts leading to her reasonable suspicion that the debtor is concealing assets from the bankruptcy estate, along with the necessity for conducting the search. Further, any inspection should be limited to regular business hours, conducted in the debtor's presence, and without forcible entry. ${ }^{171}$

Unlike the traditional warrant application, however, the trustee need not unmistakably identify in the application for the search order the specific items of property to be uncovered in the debtor's residence. As the court in Barman observed, placing such a restriction upon a bankruptcy trustee "unduly compromise[s] the trustee's ability to carry out his statutory obligations" to investigate the financial affairs of the debtor. ${ }^{172}$ Unless items of property are voluntarily disclosed by a debtor on the bankruptcy petition and schedules, a

${ }^{167} C f$. Edmondson v. United States, 402 F.2d 809, 812 (10th Cir. 1968) (applying the "neutral and detached" standard in the criminal law context (citing Aguilar v. Texas, 378 U.S. 108, $111(1964))$ ).

168 See David Sparks, Note, Searches by Environmental Protection Agencies: When Is a Warrant Necessary?, 10 J. NAT. RESOURCES \& ENVTL. L. 143, 148 (1995) (noting that administrative warrants may be obtained on an ex parte basis).

${ }^{169}$ As one commentator has correctly recognized, the element of surprise is of crucial importance in the bankruptcy context. Brandy L. Kuretich, Comment, Bankruptcy and the Fourth Amendment: Should the Test Be "Reasonable" or "Administrative?," 81 U. DET. MERCY L. REV. 31, 53 (2003). That is, "[i]f the debtor has warning that the trustee is coming to conduct an inventory of the assets stored at his residence, he will have an opportunity to transfer those hidden assets to another location and further hinder or delay the Trustee's ability to uncover assets for the benefit of creditors." Id.

${ }^{170}$ Nat'1 Treasury Emps. Union v. Von Raab, 489 U.S. 656, 667-68 (1989) ("Our cases teach, however, that the probable-cause standard 'is peculiarly related to criminal investigations.' In particular, the traditional probable-cause standard may be unhelpful in analyzing the reasonableness of routine administrative functions ...." (citations omitted)); see also United States v. Roux Labs., Inc., 456 F. Supp. 973, 977 (M.D. Fla. 1978) ("To be sure, the administrative inspection search is of a different character than a criminal search. The kind of showing of probable cause for an administrative search warrant is different because it varies from one situational context to another, unlike the single standard of probable cause needed to obtain a criminal search warrant." (footnote omitted) (citing Marshall v. Barlow's, Inc., 436 U.S. 307, 320 (1978))); cf. Griffin v. Wisconsin, 483 U.S. 868,873 (1987) (noting that in the administrative context, a warrant need not be obtained upon a showing of probable cause so long as the search meets "reasonable legislative or administrative standards" (quoting Camara, 387 U.S. at 538)); Montville v. Lewis, 87 F.3d 900, 903 (7th Cir. 1996) (concluding same).

${ }^{171}$ Indeed, the Barman court utilized such parameters. See Taunt v. Barman (In re Barman), 252 B.R. 403, 418 (Bankr. E.D. Mich. 2000).

172 Id. at 419. 
trustee has no way of knowing what property the debtor may be possessing behind the concrete walls of her residence. Consequently, requiring a trustee to itemize with specificity the property believed to be on the premises only serves to "reward the dishonest or sloppy debtor."173

While not in the bankruptcy context, a search order issued pursuant to the All Writs Act has been approved indirectly by at least two different courts. In United States $v$. Goodridge, the federal government filed a motion under the All Writs Act seeking an order compelling two individuals to provide blood samples for blood type and DNA testing. ${ }^{174}$ The purpose of the request was to help assist the government in identifying whose blood was uncovered in a getaway car used in a bank robbery. ${ }^{175}$ The individuals did not contest that the All Writs Act could provide the court with the power to issue the order, and the court did not question whether such an order could emanate from the All Writs Act. ${ }^{176}$ Rather, the individuals argued that the government's request amounted to a search for evidence which must first be measured by the Fourth Amendment. ${ }^{177}$ The district court agreed with this argument, requiring that the government demonstrate "search warrant standards" prior to any issuance of a search order under the All Writs Act. ${ }^{178}$

In United States $v$. Kone, ${ }^{179}$ Falikou Kone was "serving a federal term of supervised release, but no statute, special condition of release, or regulation authorized a warrantless search of his home."180 While on supervised release, the U.S. Probation Office suspected Kone of manufacturing and possessing fraudulent checks. ${ }^{181}$ Consequently, the Probation Office filed an affidavit with the district court requesting that a search order be issued for Kone's residence and automobiles. ${ }^{182}$ Recognizing that officials from the Probation Office are not considered law enforcement officers within the meaning of Federal Rule of Criminal Procedure 41, 183 the Probation Office sought the search order under the All Writs Act. ${ }^{184}$ The district court granted the search order. ${ }^{185}$ Following the execution of the order, Kone moved to suppress evidence uncovered in his home and challenged the order under the Fourth Amendment. ${ }^{186}$ In measuring the order against the Fourth Amendment, the court concluded that the government needed to obtain a search warrant prior to conducting any search of

${ }^{173}$ Id.

${ }^{174}$ United States v. Goodridge, 945 F. Supp. 371, 372 (D. Mass. 1996).

${ }^{175} \mathrm{Id}$.

${ }_{176}$ Id.

${ }^{177}$ Id.

178 Id. at 373.

179591 F. Supp. 2d 593 (S.D.N.Y. 2008).

180 Id. at 597.

181 Id.

182 Id.

183 Id. at 599.

${ }^{184}$ Id. at 598.

185 Kone, 591 F. Supp. 2d at 598.

186 Id. at 597. 
Kone's home. ${ }^{187}$ The court, however, held that the search order failed to comply with the Fourth Amendment because it did not issue upon a finding of probable cause. ${ }^{188}$ Significantly, though, the court did not strike down the propriety of a court issuing a search order under the All Writs Act. Rather, the order proved defective because it failed to issue upon a finding of probable cause, as would a more traditional search warrant under Federal Rule of Criminal Procedure $41 .{ }^{189}$

It is reasonable to presume that a search order can be issued under the authority of the All Writs Act. But as previously conceded, the use of the All Writs Act to order a search of a debtor's home is not without criticism. ${ }^{190}$ The Supreme Court's reference to "historic aids," namely common law writs, ${ }^{191}$ in United States v. New York Telephone Co., ${ }^{192}$ along with the fact that the All Writs Act imbues federal courts with essentially equitable powers, ${ }^{193}$ raises the question of whether an order to search a home was a remedy available at common law ${ }^{194}$ or in equity. ${ }^{195}$ As the Supreme Court concluded in Grupo Mexicano de Desarrollo, S.A. v. Alliance Bond Fund, Inc., ${ }^{196}$ the equity jurisdiction of the federal courts extends only so far as the equity jurisprudence exercised by the High Court of Chancery in England at the time of the adoption of the Judiciary Act of 1789, which conferred jurisdiction on the federal courts

$$
\begin{aligned}
& { }^{187} \mathrm{Id} \text {. at } 608 . \\
& { }^{188} \mathrm{Id} \text {. } \\
& { }^{189} \mathrm{Id} \text {. at } 610 . \\
& { }^{190} \mathrm{See} \text { supra Part IV. } \\
& \mathrm{I} \text { Se }
\end{aligned}
$$

${ }^{191}$ Some of the traditional common law writs included writs of mandamus, prohibition, certiorari, injunction, subpoena, habeas corpus, ne exeat and coram nobis. Wacker, supra note 129 , at $52 \mathrm{n} .94$.

192434 U.S. 159, 173, 187 (1977).

193 William P. Glenn, Jr., Ex-Parte Seizure of Intellectual Property Goods, 9 TEX. INTELL. PROP. L.J. 307, 318 (2001).

${ }^{194}$ Brian M. Hoffstadt, Common-Law Writs and Federal Common Lawmaking on Collateral Review, 96 Nw. U. L. REV. 1413, 1461 (2002) ("Because the [All Writs] Act is . . broadly worded, the courts have necessarily resorted to the common law to determine which writs are available, and under which circumstances they may be issued."); Fruqan Mouzon, Forgive Us Our Trespasses: The Need for Federal Expungement Legislation, 39 U. MEM. L. REv. 1, 18 (2008) ("To give some contours to the exercise of their discretion, when justice so requires, federal courts may, under the All Writs Act, use the historic common law writs.").

${ }^{195}$ See ITT Cmty. Dev. Corp. v. Barton, 569 F.2d 1351, 1359 (5th Cir. 1978) (noting that the All Writs Act "provide[s] a federal court with various common law equity devices to be used incidental to the authority conferred on the court"); see also Alan M. Ahart, Preliminary Asset Freezes in the Bankruptcy Courts, 28 CAL. BANKR. J. 125, 133 (2006) (arguing that in accordance with Supreme Court precedent, the All Writs Act does not confer any authority on a federal court "beyond the general equitable power of a federal district court").

196527 U.S. 308 (1999). 
over all suits in equity. ${ }^{197}$ Consequently, it must be examined whether a traditional court of equity could order the search of a debtor's home or whether such a remedy could only be fashioned by a common law court. ${ }^{198}$ If courts of equity were unable to do so, then a similar restraint might be placed on a modern bankruptcy court relying upon the All Writs Act as its source of authority.

Historically, courts of equity administered remedies for rights not recognized by common law courts or for the prevention of wrongs for which the common law did not provide an adequate remedy. ${ }^{199}$ The power of English courts of equity to fashion appropriate remedies has been described as "extraordinary jurisdiction." 200 The matters in which equity could operate included, among others, protecting trusts and equitable estates, correcting injuries arising by accident or mistake, preventing unconscionable bargains, enforcing action for creditors utilizing setoff or marshaling, or compelling the performance of a duty the commission of which would inflict irreparable injury on a person. ${ }^{201}$ To effectuate its ruling, courts of equity would issue writs or bills upon affected parties. ${ }^{202}$ With respect to creditor-debtor relations, traditional writs or bills in equity included writs of ne exeat republica, ${ }^{203}$ creditor bills of discovery, ${ }^{204}$ writs of execution, ${ }^{205}$ and writs of injunction. ${ }^{206}$

${ }^{197}$ Id. at 318; see also 3 Roger Foster, A Treatise ON Federal PRACTICE Civil AND CrIminal $\S 5$ (4th ed. 1909) ("The jurisdiction in equity of the Federal courts is, subject to the limitations of the Constitution, substantially the same as that of the English Court of Chancery....").

198 See U.S. Alkali Exp. Ass'n v. United States, 325 U.S. 196, 201-02 (1945) (permitting the use of the common law writs of certiorari, mandamus, and prohibition under the All Writs Act); see also Hoffstadt, supra note 194, at 1416-17 (2001) (contending that the All Writs Act enables federal courts to issue common law writs so long as they are necessary or in aid of the court's jurisdiction).

${ }^{199}$ FOSTER, supra note $197, \S 2$.

${ }^{200}$ Geo. TuCKER BisPham, The Principles of EquTtY: A TrEatise on the System of JUSTICE ADMINISTERED IN COURTS OF CHANCERY 2 (10th ed. 1922).

201 Foster, supra note 197, § 2; see also WILlIAM MEADE Fletcher, A Treatise on

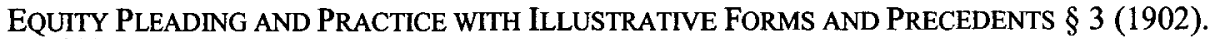

202 See generally 2 FOSTER, supra note 197, $\S 361$ (describing the writ process).

${ }^{203}$ Charles Fisk BEACH, JR., A TREATISE ON THE MODERN PRACTICE IN EQUITY IN THE STATE AND FEDERAL COURTS OF THE UNITED STATES, with PARTICULAR REFERENCE TO THE PRACTICE IN THE FEDERAL COURTS $\S 607$ (Cincinnati, W.H. Anderson \& Co 1894). The writ of ne exeat republica was a prerogative writ that placed a person in custody so as to prevent her from leaving a particular state or the United States. Id.

${ }^{204}$ Elliott v. Kyle, 57 So. 752, 753-54 (Ala. 1912); FlETCHER, supra note 201, at $\S \S 804-824$.

205 FLETCHER, supra note 201, $\$ 734$.

${ }^{206}$ Morrow v. Dist. of Columbia, 417 F.2d 728, 733 (D.C. Cir. 1969). 
At common law, a court could issue a writ of scire facias ${ }^{207}$ or a writ of attachment. ${ }^{208}$

There appears to have been no specific writ at equity or common law that authorized the search of a residence. However, if it is truly the case that the Supreme Court in Grupo Mexicano requires a reference to English chancery and common law practice for the scope of a federal court's authority under the All Writs Act, then one cannot ignore the controversial writ of assistance issued by courts of equity in England and in the American colonies prior to 1789. In its modern form, a writ of assistance is akin to a writ of possession at law, whereby a court orders the transfer of title to and possession of real property based upon a previously entered decree. ${ }^{209}$ Historically, a writ of assistance could also be issued commanding an officer of the court to put a party in possession of property to which she is entitled. This writ authorized a sheriff to search and "break open all necessary doors, if the possession be not quietly delivered."210 More significantly, the writ of assistance was often utilized to place property into the hands of receivers, ${ }^{211}$ a position that functions akin to today's bankruptcy trustee.

More generally, the writs of assistance utilized in pre-revolutionary America were akin to general search warrants "that permitted the authorities to search anywhere they pleased for any reason-or for no reason." 212 This included searches of homes, oftentimes in search of uncustomed goods. ${ }^{213}$ The writs of assistance and general warrants were "anathema in the colonies"214 and served in part as a catalyst for the Revolution and for the Fourth Amendment's

${ }^{207}$ A writ of scire facias issued in favor of a party attempting to enforce or execute upon a judgment previously obtained. 2 FOSTER, supra note $202, \S 368 \mathrm{~b}$.

${ }^{208} I d$. $\S 369$. A writ of attachment was used by creditors either to obtain jurisdiction over a debtor or to sequester property owned by the debtor to satisfy a future judgment.

${ }^{209}$ S. State Bank v. Leverette, 123 S.E. $68,69-70$ (N.C. 1924).

${ }^{210}$ FLETCHER, supra note 201, § 736.

211 Id. $\S 736$.

212 Thomas K. Clancy, The James Otis Lectures: Annual Lecture Series on Search and Seizure Principles, 76 MISS. L.J. 581, 581-82 (2006).

213 Amar, Writs of Assistance, supra note 151, at 77.

${ }^{214}$ Maclin, The Complexity of the Fourth Amendment, supra note 151, at 945 (citation omitted). For an in-depth treatment of the history of general warrants and writs of assistance in the American colonies, see generally id.; Amar, supra note 151; Clancy, supra note 151; Thomas K. Clancy, The Framers' Intent: John Adams, His Era, and the Fourth Amendment, 86 IND. L.J. 979 (2011); Thomas Y. Davies, Recovering the Original Fourth Amendment, 98 MICH. L. REV. 547 (1999); Tracey Maclin, The Central Meaning of the Fourth Amendment, 35 WM. \& MARY L. REV. 197 (1993); Tracey Maclin, When the Cure for the Fourth Amendment Is Worse than the Disease, 68 S. CAL. L. REV. 1 (1994); M. Blane Michael, Reading the Fourth Amendment: Guidance from the Mischief that Gave It Birth, 85 N.Y.U. L. REV. 905 (2010); David E. Steinberg, An Original Misunderstanding: Akhil Amar and Fourth Amendment History, 42 SAN DIEGo L. REV. 227 (2005); and David E. Steinberg, High School Drug Testing and the Original Understanding of the Fourth Amendment, 30 HASTINGS CONST. L.Q. 263 (2003). 
inclusion in the Constitution. ${ }^{215}$ By all accounts, the Fourth Amendment served to remedy and prevent writs of assistance and general warrants from issuing in America after the adoption of the Constitution. ${ }^{216}$

I am certainly not advocating for a return of the general warrant under the auspices of the All Writs Act. Instead, I make the observation of the writs of assistance simply to support an argument that since the authority to order a search of a home existed in England in the late eighteenth century, then perhaps the power to order a search can find authority in the All Writs Act despite the limitations espoused by the Grupo Mexicano Court. Importantly though, any order to search made pursuant to the All Writs Act would still need to comply with the mandates of the Fourth Amendment.

\section{B. Section 105 of the Bankruptcy Code as a Source of Authority to Issue a Search Warrant}

In addition to relying upon the All Writs Act, a bankruptcy court may also reasonably rely upon $\S 105$ of the Bankruptcy Code as a source of authority to issue a search order of a debtor's home. Section 105(a) of the Bankruptcy Code provides in relevant part that a bankruptcy court "may issue any order, process, or judgment that is necessary or appropriate to carry out the provisions of this title."217 This provision derives from section 2(a)(15) of the Bankruptcy Act of 1898 , which in turn takes its origins directly from the Federal All Writs Act. ${ }^{218}$

215 Fabio Arcila, Jr., In the Trenches: Searches and the Misunderstood Common-Law History of Suspicion and Probable Cause, 10 U. PA. J. CONST. L. 1, 10 (2007).

${ }^{216}$ Payton v. New York, 445 U.S. 573, 583 (1980) ("It is familiar history that indiscriminate searches and seizures conducted under the authority of 'general warrants' were the immediate evils that motivated the framing and adoption of the Fourth Amendment."); Dist. of Columbia v. Little, 178 F.2d 13, 19 (D.C. Cir. 1950) ("It is true that the incident which gave rise to the furor in England and to the fears in this country was the invention of general warrants designed to accomplish an invasion of homes. And the adopters of the [Fourth] Amendment certainly intended to forestall any such in this country.").

21711 U.S.C. $\$ 105($ a) (2006).

218 Daniel B. Bogart, Resisting the Expansion of Bankruptcy Court Power Under Section 105 of the Bankruptcy Code: The All Writs Act and an Admonition from Chief Justice Marshall, 35 ARIZ. ST. L.J. 793, 799 (2003). Section 2(a)(15) of the former Bankruptcy Act provided as follows:

(a) The courts of the United States hereinbefore defined as courts of bankruptcy are hereby created courts of bankruptcy and are hereby invested, within their respective territorial limits as now established or as they may be hereafter changed, with such jurisdiction at law and in equity as will enable them to exercise original jurisdiction in proceedings under this title, in vacation, in chambers, and during their respective terms, as they are now or may be hereafter held, to- 
Much like the "in aid of jurisdiction" component of the All Writs Act, it has been held that the original purpose of section 2(a)(15) was to provide a bankruptcy court with the power to "protect its custody of the estate and the administration thereof." 219 Indeed, the legislative history to $\S 105$ evinces the connection to the All Writs Act, providing that "[s]ection 105 is similar in effect to the All Writs Statute... The section is repeated here for the sake of continuity from current law and ease of reference, and to cover any powers traditionally exercised by a bankruptcy court that are not encompassed by the All Writs Statute."220

Despite its lineage from the All Writs Act, in its modern incantation $\S 105$ has become an "omnibus provision"221 which serves as the basis for bankruptcy courts to claim to possess and exercise broad powers in the administration of a bankruptcy case. ${ }^{222}$ Despite the well-accepted notion that bankruptcy courts are courts of equity, and thereby imbued with broad powers to fashion relief in bankruptcy cases, 223 it is equally understood that a bankruptcy court's power under $\S 105$ is not boundless. In this regard, the Supreme Court has expressed that any grant of authority given to the bankruptcy courts pursuant to $\S 105$ must be exercised within the confines of the Bankruptcy Code. ${ }^{224}$ That is, a

(15) Make such orders, issue such process, and enter such judgments, in addition to those specifically provided for, as may be necessary for the enforcement of the provisions of this title....

11 U.S.C. § 11(a)(15) (1976) (repealed 1978).

219 Gonzalez Hernandez v. Borgos, 343 F.2d 802, 807 (1st Cir. 1965).

${ }^{220}$ H.R. REP. NO. 95-595, at 316-17 (1978), reprinted in 1978 U.S.C.C.A.N. 5963, 6273-74; see also Bird v. Carl's Grocery Co. (In re NWFX, Inc.), 864 F.2d 593, 595 (8th Cir. 1989) ("Section 105 is comparable to the All Writs Statute ... ."); In re Sauer, 223 B.R. 715, 726 (Bankr. D.N.D. 1998) (noting same).

2212 COLLIER ON BANKRUPTCY 105.01 (Alan N. Resnick \& Henry J. Sommer eds., 16 th ed. 2009).

222 See, e.g., United States v. Energy Res. Co., 495 U.S. 545, 549 (1990) (noting that pursuant to $\S 105(\mathrm{a})$, "bankruptcy courts, as courts of equity, have broad authority to modify creditor-debtor relationships"); Dalton Dev. Project \#1 v. Unsecured Creditors Comm. (In re UniOil), 948 F.2d 678, 682 (10th Cir. 1991) ("The bankruptcy judge has the power to issue any order which is necessary or appropriate to protect the debtor's estate."); In re Comer Home Care, Inc., 438 B.R. 122, 126 (Bankr. W.D. Ky. 2010) ("But it must be recognized that $\S 105$ (a) grants broad equitable powers over the administration of a case and therefore any decision is well within the discretion of the court."); In re Lucero, 408 B.R. 348, 351 (Bankr. C.D. Cal. 2009) (holding that a bankruptcy court "has broad statutory authority under 11 U.S.C. $\S 105$ to fashion suitable relief consistent with bankruptcy's principles of fairness and equity favoring debtors").

223 Manuel D. Leal, The Power of the Bankruptcy Court: Section 105, 29 S. TEX. L. REV. 487, 490 (1987) ("There is general agreement that Congress has expressly granted very broad powers in section 105 to judges exercising federal bankruptcy jurisdiction.").

${ }^{224}$ Marrama v. Citizens Bank of Mass., 549 U.S. 365, 382 (2007) (citing Norwest Bank Worthington v. Ahlers, 485 U.S. 197, 206 (1988)); $c f$. Raleigh v. Ill. Dep't of Revenue, 530 U.S. 15, 24-25 (2000) ("Bankruptcy courts are not authorized in the name of equity to make 
bankruptcy court "may exercise its equitable power only as a means to fulfill some specific code provision; it may not use its equitable powers to achieve a result not contemplated by the code."225 The power bestowed to a bankruptcy court by $\S 105$ may also not be used to override explicit provisions in other sections of the Bankruptcy Code. ${ }^{226}$ Furthermore, a bankruptcy court cannot invoke $\S 105(\mathrm{a})$ to create substantive rights not otherwise provided by the Bankruptcy Code or "to constitute a roving commission to do equity."227

At present, the applicable case law and scholarly literature reflect two divergent schools of thought regarding the breadth of $\S 105.228$ The first school adopts a liberal interpretation of $\S 105$, thereby enabling a court to fashion relief and craft remedies in order to fill gaps left by the statutory language of the Bankruptcy Code. ${ }^{229}$ Professor Daniel Bogart offers the following examples of bankruptcy courts utilizing $\S 105$ expansively to issue orders or to take actions for which the Bankruptcy Code does not specifically provide: (1) ordering the partial discharge of student loans despite the presumption of $\S 523(\mathrm{a})(8)$ of the Bankruptcy Code $^{230}$ that none of a debtor's educational student loans are

wholesale substitution of underlying law controlling the validity of creditors' entitlements, but are limited to what the Bankruptcy Code itself provides.").

${ }^{225}$ Murgillo v. Cal. State Bd. of Equalization (In re Murgillo), 176 B.R. 524, 531 (B.A.P. 9th Cir. 1995) (citing Norwest, 485 U.S. at 206).

${ }^{226}$ In re Sec. \& Energy Sys., Inc., 62 B.R. 676, 678 (Bankr. W.D.N.Y. 1986).

${ }^{227}$ In re First RepublicBank Corp., 95 B.R. 58, 60 (Bankr. N.D. Tex. 1988) (citing United States v. Sutton, 786 F.2d 1305, 1308 (5th Cir. 1986)); see also In re WAPI, Inc., 171 B.R. 130, 133 (Bankr. N.D. Ala. 1994) (noting same).

${ }^{228}$ COLLIER, supra note 221 , 105.01 . For an in-depth treatment on the issue of a bankruptcy court's power under $\S 105$ in the scholarly literature, see Bogart, supra note 218 , at 805-06; Leal, supra note 223, at 490; Brian Leepson, A Case for the Use of a Broad Court Equity Power to Facilitate Chapter 11 Reorganization, 12 EMORY BANKR. DEV. J. 775, 776 (1996); Steve H. Nickles \& David G. Epstein, Another Way of Thinking About Section 105(a) and Other Sources of Supplemental Law Under the Bankruptcy Code, 3 CHAP. L. REV. 7 (2000); see also Smart World Techs., LLC v. Juno Online Servs., Inc. (In re Smart World Techs., LLC), 423 F.3d 166, 183 (2d Cir. 2005) (noting the disagreement among circuit courts over how broadly to construe a bankruptcy court's power under $\S 105$ ).

${ }^{229}$ ColliER, supra note 221, 105.01; see also Leepson, supra note 228, at 795-96 (arguing for an expansive interpretation of $\S 105$ in the Chapter 11 context).

${ }^{230}$ Section 523 of the Bankruptcy Code excepts certain types of debts from an individual debtor's discharge. In particular, $\S 523(\mathrm{a})(8)$ creates a presumption that educational loans are not dischargeable in bankruptcy absent an individual debtor satisfying a rigid "undue hardship" standard. Law v. Educ. Res. Inst., Inc. (In re Law), 159 B.R. 287, 291 (Bankr. D.S.D. 1993). Section 523(a)(8) provides as follows:

A discharge under section $727,1141,1228(a), 1228(b)$, or $1328(b)$ of this title does not discharge an individual debtor from any debt-

…

(8) unless excepting such debt from discharge under this paragraph would impose an undue hardship on the debtor and the debtor's dependents, for- 
dischargeable;231 (2) extending the "automatic stay" to non-debtor third parties, despite the language of $\$ 362$ making the stay applicable only to the debtor and to the bankruptcy estate; 232 (3) permitting the "substantive consolidation" of two different bankruptcy estates; ${ }^{233}$ (4) issuing "first day orders" in Chapter 11

(A)(i) an educational benefit overpayment or loan made, insured, or guaranteed by a governmental unit, or made under any program funded in whole or in part by a governmental unit or nonprofit institution; or

(ii) an obligation to repay funds received as an educational benefit, scholarship, or stipend; or

(B) any other educational loan that is a qualified education loan, as defined in section 221(d)(1) of the Internal Revenue Code of 1986, incurred by a debtor who is an individual.

11 U.S.C. § 523(a)(8) (2006).

${ }^{231}$ Bogart, supra note 218, at 805-06 ("And, in fact, notwithstanding the absence of language in the provision that might directly provide bankruptcy courts with the power to grant a partial discharge, bankruptcy courts have done so, relying on section 105 and the equitable power of bankruptcy courts." (footnotes omitted)). For decisions that have granted a partial discharge of student loan debt, see, for example, Miller v. PHEAA (In re Miller), 377 F.3d 616, 620-21 (6th Cir. 2004), and Myers v. Fifth Third Bank (In re Myers), 280 B.R. 416, 420 (Bankr. S.D. Ohio 2002).

232 At the moment a bankruptcy petition is filed, $\S 362$ of the Bankruptcy Code automatically establishes a stay against a debtor's creditors from seeking to collect on their debts from either the debtor or the bankruptcy estate. 11 U.S.C. $\S 362(a)$. As Professor Bogart correctly notes, "Section 362 does not provide relief from process to any parties other than the debtor. Nevertheless, a variety of courts have relied upon section 105 to grant relief to third persons who have found themselves subject to claims by creditors of the debtor." Bogart, supra note 218, at 807. Most often, these third parties are insiders of a corporate Chapter 11 debtor, such as a chief operating officer, or family members of an individual debtor who may have provided a guaranty for some of the debtor's obligations. Id. at $807-$ 08. For decisions that have extended the automatic stay to non-debtor third parties, see, for example, In re Phila. Newspapers, LLC, 407 B.R. 606, 616 (E.D. Pa. 2009) (extending the automatic stay to protect a non-debtor, third-party chief executive officer of the corporate debtor where the debtor had contractual duties to indemnify the officer), and In re Adelphia Commc'ns Corp. v. Associated Electric \& Gas Ins. Servs., Ltd. (In re Adelphia Commc'ns Corp.), 302 B.R. 439, 449-55 (Bankr. S.D.N.Y. 2003) (staying non-bankruptcy litigation seeking the rescission of director and officer liability policies where an adjudication of rescission would affect the corporate debtor's reorganization process).

233 When ordered by a bankruptcy court, "[s]ubstantive consolidation results in the pooling of the assets of, and claims against, two or more entities, thereby satisfying liabilities from the resultant common fund, eliminating duplicate claims, and combining the creditors of the two entities for purposes of voting on reorganization plans." Lisanti v: Lubetkin (In re Lisanti Foods, Inc.), 329 B.R. 491, 497 (D.N.J. 2005). For decisions that have granted the substantive consolidation of separate entities pursuant to $\S 105$, see, for example, FDIC v. Colonial Realty Co., 966 F.2d 57, 61 (2d Cir. 1992) (utilizing $\$ 105$ and upholding the substantive consolidation between a debtor general partnership and two debtor individual general partners), and Eastgroup Props. v. S. Motel Assocs., Ltd., 935 F.2d 245, 250-52 (11th Cir. 1991) (substantively consolidating a commonly owned debtor corporation and debtor limited partnership). But see J. Maxwell Tucker, Substantive Consolidation: The 
cases whereby a corporate debtor seeks to make payments post-petition to certain essential creditors on their pre-petition claims though such conduct violates the statutorily mandated order of priority among creditors; ${ }^{234}$ (5) "recharacterizing" claims of insiders as equity interests,;35 and (6) granting creditors the ability to file late claims or late non-dischargeability complaints. ${ }^{236}$

The second school of thought interprets $\S 105$ restrictively and thus considers a bankruptcy court's equitable power under this section to be narrowly defined. ${ }^{237}$ As Judge Manuel D. Leal explains, "Application of this restrictive approach is partly due to the constitutional ramifications surrounding the authority of federal bankruptcy judges who receive their jurisdiction through a reference from Article III."238 Like Leal, scholars such as Professor Bogart and Professors Steven Nickles and David Epstein argue against a liberal reading of $\S 105$, contending that judicial rulemaking under the guise of equitable powers enables bankruptcy courts to circumvent a statute created by Congress, thereby causing "a breach in the constitutionally required separation of powers." 239 These are reasonable arguments, and this Article does not question their soundness or correctness. Nonetheless, it remains the case that in practice the boundaries of a bankruptcy court to act pursuant to $\S 105$ in various circumstances are not clear and uniform among the nation's bankruptcy courts. ${ }^{240}$

Cacophony Continues, 18 AM. BANKR. INST. L. REV. 89, 116 (2010) (arguing that $\S 105$ does not authorize a bankruptcy court to order the substantive consolidation of separate estates).

${ }^{234}$ Bogart, supra note 218, at 811-19. For decisions permitting the use of $\S 105$ to issue first-day orders, see, for example, In re Wehrenberg, Inc., 260 B.R. 468, 469 (Bankr. E.D. Mo. 2001), and In re Just For Feet, Inc., 242 B.R. 821, 826 (D. Del. 1999).

$235 \mathrm{~A}$ bankruptcy court might recharacterize a purported claim to an equity interest in order to prevent an equity investor from labeling her contribution as a loan, thereby "circumventing the Bankruptcy Code's priority system by guaranteeing itself a larger recovery and higher priority if the debtor files for bankruptcy." Menotte v. NLC Holding Corp. (In re First NLC Fin. Servs., LLC), 396 B.R. 562, 567 (Bankr. S.D. Fla. 2008). For decisions recharacterizing debt to equity pursuant to $\S 105$, see, for example, GMBH v. Official Comm. of Unsecured Creditors (In re Official Comm. of Unsecured Creditors for Dornier Aviation (North America), Inc.), 453 F.3d 225, 229 (4th Cir. 2006), and Leesa Bunch \& McMasker Enters., Inc. v. J.M. Capital Fin., Ltd. (In re Hoffinger Indus., Inc.), 327 B.R. 389, 407-11 (Bankr. E.D. Ark. 2005).

236 See, e.g., Nicholson v. Isaacman (In re Isaacman), 26 F.3d 629, 635-36 (6th Cir. 1994) (permitting a creditor to file a non-dischargeability complaint past the reported bar date); Anwiler v. Patchett (In re Anwiler), 958 F.2d 925, 930 (9th Cir. 1992) (holding same).

${ }^{237}$ See, e.g., Carlos J. Cuevas, Bankruptcy Code Section 105(a) Injunctions and State and Local Administrative and Civil Enforcement Proceedings, 4 AM. BANKR. INST. L. REV. 365, 371-72 (1996).

${ }^{238}$ Leal, supra note 223 , at 490 .

${ }^{239}$ Bogart, supra note 218 , at 820 ; Nickles \& Epstein, supra note 228 , at 18 ("The constitutional problem is not so much in Congress delegating wide powers to the courts through $[\S]$ 105(a). The real problem is that in exercising such wide powers, the courts are making law to the extent of violating the constitutional separation of powers.").

${ }^{240}$ COLLIER, supra note 221, f 105.01 [2]. 
Thus, to the extent a bankruptcy court favors a liberal reading of $\S 105,241$ or is simply inclined to order such relief given the factual circumstances of a debtor allegedly concealing assets from the estate, it remains uncertain whether a bankruptcy court could exercise its powers to issue a search warrant to a trustee. Four reasons militate in favor of concluding that $\S 105$ could be utilized to fashion such relief.

First, one criticism lodged against the expansive use of $\S 105$ is that the section itself provides that a court may issue any order necessary or appropriate to carry out the provisions of the Bankruptcy Code, and not the policy objectives or goals underlying the federal bankruptcy laws. ${ }^{242}$ Stated slightly differently, the exercise of $\S 105$ power should be tied to another section of the Bankruptcy Code, and not used as a source of independent authority. ${ }^{243}$ Unlike relief such as substantive consolidation and first-day orders which find no basis or expression in another Bankruptcy Code provision, the issuance of a search order for a debtor's residence can reasonably be tied to at least two existing provisions of the Bankruptcy Code. Section 704 of the Code outlines the duties of a bankruptcy trustee. ${ }^{244}$ In a Chapter 7 or Chapter 13 case, ${ }^{245}$ the trustee is

241 One notable bankruptcy authority contends that "[g]iven the broad mandate to bankruptcy courts generally to reorganize debtors, to afford a fresh start to debtors and to distribute funds equitably to creditors, an expansive construction [of $\S 105$ ] is justified." Id.

${ }^{242}$ Bogart, supra note 218, at 803-04; see also New Eng. Dairies, Inc, v. Dairy Mart Convenience Stores, Inc. (In re Dairy Mart Convenience Stores, Inc.), 351 F.3d 86, 92 (2d Cir. 2003) ("The statutory language supports this limit on the equitable powers of the bankruptcy court. The equitable power conferred on the bankruptcy court by section 105(a) is the power to exercise equity in carrying out the provisions of the Bankruptcy Code, rather than to further the purposes of the Code generally, or otherwise to do the right thing. This language 'suggests that an exercise of section 105 power be tied to another Bankruptcy Code section and not merely to a general bankruptcy concept or objective."' (citing CoLLIER, supra note 221, \ 105.01[1])).

243 Solow v. Kalikow (In re Kalikow), 602 F.3d 82, 97 (2d Cir. 2010) (citing COLLIER, supra note 221 , I 105.01[1]).

${ }^{244}$ Section 704(a) of the Bankruptcy Code provides as follows:

The trustee shall-

(1) collect and reduce to money the property of the estate for which such trustee serves, and close such estate as expeditiously as is compatible with the best interests of parties in interest;

(2) be accountable for all property received;

(3) ensure that the debtor shall perform his intention as specified in section

$521(2)(B)$ of this title;

(4) investigate the financial affairs of the debtor;

(5) if a purpose would be served, examine proofs of claims and object to the allowance of any claim that is improper;

(6) if advisable, oppose the discharge of the debtor;

(7) unless the court orders otherwise, furnish such information concerning the estate and the estate's administration as is requested by a party in interest;

(8) if the business of the debtor is authorized to be operated, file with the court, with the United States trustee, and with any governmental unit charged with 
statutorily charged with the responsibility of collecting property of the estate and investigating the financial affairs of the debtor. ${ }^{246}$ If a trustee has reasonable cause to believe that a debtor is concealing assets from the bankruptcy proceeding, then the trustee cannot fully carry out her statutory mandate without assistance from the court authorizing a search. In other words, on those rare occasions when a search of a debtor's home might be necessary, obtaining a warrant from the court is a mechanism for a trustee to fulfill her specific duties under $\S 704$ of the Bankruptcy Code.

In addition, $\S 541$ of the Bankruptcy Code provides that upon commencement of a bankruptcy case, an estate is comprised of "all legal or equitable interests of the debtor in property." 247 At such time, the bankruptcy estate falls under the control and jurisdiction of the bankruptcy court. ${ }^{248}$ The estate exists apart from the debtor, and acts through its legal representative, the bankruptcy trustee. ${ }^{249}$ Again, if grounds exist to believe that a debtor has been less than forthcoming regarding the extent of her assets, a search warrant can be viewed as a tool for a bankruptcy trustee and the court to aggregate fully the

responsibility for collection or determination of any tax arising out of such operation, periodic reports and summaries of the operation of such business, including a statement of receipts and disbursements, and such other information as the United States trustee or the court requires;

(9) make a final report and file a final account of the administration of the estate with the court and with the United States trustee;

(10) if with respect to the debtor there is a claim for a domestic support obligation, provide the applicable notice specified in subsection (c);

(11) if, at the time of the commencement of the case, the debtor (or any entity designated by the debtor) served as the administrator (as defined in section 3 of the Employee Retirement Income Security Act of 1974) of an employee benefit plan, continue to perform the obligations required of the administrator; and

(12) use all reasonable and best efforts to transfer patients from a health care business that is in the process of being closed to an appropriate health care business that-

(A) is in the vicinity of the health care business that is closing;

(B) provides the patient with services that are substantially similar to those provided by the health care business that is in the process of being closed; and

(C) maintains a reasonable quality of care.

11 U.S.C. $\$ 704(a)(2006)$.

245 The main duties of a bankruptcy trustee contained in $\S 704$ are made applicable to Chapter 13 bankruptcy cases under $\S 1302$ (b)(1). See id. $\S 1302$ (b).

246 Id. $\S 704(\mathrm{a})(1),(4)$.

247 Id. $§ 541(\mathrm{a})(1)$.

248 Straton v. New, 283 U.S. 318,321 (1931) ("The filing of the petition is an assertion of jurisdiction with a view to the determination of the status of the bankrupt and a settlement and distribution of his estate. This jurisdiction is exclusive within the field defined by the law, and is so far in rem that the estate is regarded as in custodia legis from the filing of the petition.").

${ }^{249}$ In re Raynard, 327 B.R. 623, 628 n.9 (Bankr. W.D. Mich. 2005) (citing 11 U.S.C. $\S 323(\mathrm{a}))$. 
bankruptcy estate and thereby protect its jurisdiction. Indeed, $\S 105$ has been employed in the past by bankruptcy courts to protect the assets of the estate. ${ }^{250}$ Permitting a bankruptcy trustee to search a debtor's home through the auspices of a search warrant furthers the task of protecting the estate. Section 521(a)(4) works in tandem with $\S 541(\mathrm{a})(1)$, whereby the former prescribes that if a trustee is serving in the case, then the debtor has a statutory duty to surrender to the trustee all property of the estate..$^{251}$ The concealment of assets by a debtor is a violation of her statutory duties and inhibits the rightful development of the bankruptcy estate.

Second, the use of $\S 105$ to issue a search warrant would not override or disregard any other section of the Bankruptcy Code. The Bankruptcy Code is silent on this front, and issuing a warrant to augment the estate and enable a trustee to administer fully the estate for the benefit of creditors permits $\S 105$ to operate as the "bankruptcy-specific gap-filling power" that it was originally intended to be. 252

Third, the liberal construction of $\S 105$ also considers the implied policy goals of bankruptcy law when fashioning relief. ${ }^{253}$ Perhaps the most widely recognized underlying policy of consumer bankruptcy law is that a discharge of indebtedness should be available only to the "honest but unfortunate debtor."254 Consequently, as a condition precedent to receiving a discharge of indebtedness, a consumer debtor must demonstrate forthrightness and honesty throughout the bankruptcy proceeding, including in the disclosures and financial information provided on the bankruptcy petition and accompanying schedules. ${ }^{255}$ Indeed, accuracy, honesty, and complete disclosure by the debtor

${ }^{250}$ Cuevas, supra note 237, at 417 (citing Lazarus Burman Assocs. v. Nat'l Westminster Bank USA (In re Lazarus Burman Assocs.), 161 B.R. 891, 897-98 (Bankr. E.D.N.Y. 1993)); see also Dalton Dev. Project \#1 v. Unsecured Creditors Comm. (In re UniOil), 948 F.2d 678,682 (10th Cir. 1991) (noting that a "bankruptcy judge has the power to issue any order which is necessary or appropriate to protect the debtor's estate").

25111 U.S.C. $\$ 521(\mathrm{a})(4)$.

252 Bogart, supra note 218, at 802; see also Bartel v. Walsh (In re Bartel), 404 B.R. 584, 591 (B.A.P. 1st Cir. 2009) ("Section 105(a) functions as a 'catch-all' provision, effectively filling in gaps to 'preserve the integrity of the bankruptcy system." (quoting Cuevas-Segarra v. Contreras, 134 F.3d 458, 459 (1st Cir. 1998))).

${ }^{253}$ COLLIER, supra note $221, \mathbb{1} 105.01$ [2].

${ }^{254}$ See Grogan v. Garner, 498 U.S. 279, 286-87 (1991) (stating that the "fresh start" provided by the Bankruptcy Code is intended for the "honest but unfortunate debtor"); see also Margaret Howard, A Theory of Discharge in Consumer Bankruptcy, 48 OHIO ST. L.J. 1047,1050 (1987) ("A second goal of bankruptcy is to reward only the honest debtor with a fresh start. Policymakers have long been concerned that bankruptcy not be a haven for the dishonest."); Charles Jordan Tabb, The Death of Consumer Bankruptcy in the United States?, 18 BANKR. DEV. J. 1, 6 (2001) ("The central tenet of the consumer bankruptcy system in America has been to offer all 'honest' individual debtors a freely-available, immediate, unconditional debt discharge in exchange for the surrender of current nonexempt assets, if any.").

${ }^{255}$ See In re Slentz, 157 B.R. 418, 420 (Bankr. N.D. Ind. 1993) ("Since the proper operation of the bankruptcy system depends, to a large extent, upon debtors honestly and 
are critical to the functioning of the bankruptcy system, and are "inherent in the bargain for the discharge." 256 Thus, if it is reasonably suspected that a debtor is abusing the bankruptcy system by attempting to shield distributable assets from the estate, then upon proper application by a bankruptcy trustee, $\S 105$ should be employed to fill the void to prevent such conduct - namely, by authorizing a search of the debtor's residence. 257

Indeed, bankruptcy law has been concerned with preventing and deterring the fraudulent debtor since at least the Middle Ages. ${ }^{258}$ For example, England promulgated the first Anglo-bankruptcy law in 1542 during the reign of King Henry VIII, ${ }^{259}$ and its primary purpose was not the rehabilitation of debtors, but the prevention of fraud by debtors upon their creditors. ${ }^{260}$ The subsequent English bankruptcy statutes treated a debtor as a criminal felon and a moral failure. ${ }^{261}$ Not only were debtors liable for imprisonment for debt, but a penalty of "pillory and the loss of an ear" could be imposed upon a debtor "who failed

forthrightly completing the schedules and statements which are filed with the court, attempts at cheating cannot be made to appear too attractive.").

${ }^{256}$ Kestell v. Kestell (In re Kestell), 99 F.3d 146, 149 (4th Cir. 1996) (citing In re Mascolo, 505 F.2d 274, 278 (1st Cir. 1974)).

${ }^{257}$ As stated, the use of $\S 105$ to issue a search order is not free from doubt. The court in Spacone v. Burke (In re Truck-A-Way) did state in passing, but without any explication or analysis, that the use of $\S 105(\mathrm{a})$, standing alone, to enable a trustee to search for allegedly hidden assets "has no basis in the Constitution, federal statutes, or caselaw." 300 B.R. 31,36 (E.D. Cal. 2003).

${ }^{258}$ Cf. Gregory E. Maggs, Consumer Bankruptcy Fraud and the "Reliance on Advice of Counsel" Argument, 69 AM. BANKR. L.J. 1, 11 (1995) ("Because bankruptcy debtors have the most to lose from the smooth functioning of these laws, they have throughout history faced the temptation to thwart the process by concealing or giving away their property.").

2598 W.S. HOLDSWORTH, A HISTORY OF ENGLISH LAW 236 (1926). This first bankruptcy law was officially titled, "An Act against such persons as do make bankrupts." Charles Jordan Tabb, The History of Bankruptcy Laws in the United States, 3 AM. BANKR. INST. L. REV. 5, 7 (1995).

${ }^{260}$ HOLDSWORTH, supra note 259 . This Act specifically recounted the common occurrence of debtors, who after

craftily obtaining into their hands great substance of other men's goods, do suddenly flee to parts unknown, or keep their houses, not minding to pay or restore to any their creditors, their debts and duties, but at their own wills and pleasures consume the substance obtained by credit of other men, for their own pleasure and delicate living, against all reason, equity, and good conscience....

An Acte Againste Suche Persones as Doo Make Bankrupte, 34 \& 35 Hen. 8, c. 4 (1542) (Eng.).

${ }^{261}$ Vern Countryman, A History of American Bankruptcy Law, 81 COM. L.J. 226, 227 (1976) ("The bankrupt who did not honestly surrender up his property and disclose his affairs was, under this law, to be 'adjudged a fraudulent bankrupt' and a felon."); see also LAWRENCE M. FRIEDMAN, A HISTORY OF AMERICAN LAW 199 (3d ed. 2005) ("Bankruptcy originally had a quite punitive ring. It was at one time a crime, later a disgrace."). 
to show that bankruptcy was due solely to misfortune."262 In addition to the power to punish, the English bankruptcy statutes empowered commissioners to investigate whether debtors were concealing assets.

The first U.S. bankruptcy law, passed in $1800,{ }^{263}$ "had as its conceptual origin the English bankruptcy system familiar to the Framers of the United States Constitution."264 Much like its English antecedents, the Bankruptcy Act of 1800 established bankruptcy fraud as a criminal offense, and jails were overflowing with imprisoned debtors in the various states. ${ }^{265}$ As the nineteenth century progressed, however, legislators in both England and the United States began to recognize a moral distinction between fraudulent debtors on the one hand, and those individuals who had succumbed to financial calamity through life's misfortunes on the other. ${ }^{266}$ The successive American bankruptcy acts, enacted in 1841, 1867 and 1898, respectively, moved slowly but surely in the direction of the liberal treatment of debtors. The modern Bankruptcy Code, enacted in 1978,267 is now considered by many to be a pro-debtor statute. Despite the pro-debtor focus of the current Bankruptcy Code, however, the potential for debtors to commit fraud, "keep house," 268 or otherwise conceal assets from the bankruptcy process remains a serious concern.

Fourth, a textual argument exists to support a broad reading of $\S 105$. The predecessor to $\S 105$, namely, $\S 2(a)(15)$ of the Bankruptcy Act, provided that a bankruptcy court may "[m]ake such orders, issue such process, and enter such

${ }^{262}$ Louis Edward Levinthal, The Early History of English Bankruptcy, 67 U. PA. L. REV. $1,17(1919)$.

263 Act of Apr. 4, 1800, ch. 19, 2 Stat. 19 (repealed 1803).

${ }^{264}$ Curry v. Castillo (In re Castillo), 297 F.3d 940, 949 (9th Cir. 2002); see also DAVID A. SKEEL, JR., DEBT'S DOMINION: A HISTORY OF BANKRUPTCY LAW IN AMERICA 90 (2001) ("The Bankruptcy Act of 1800 was derived from English law, as were parts of the 1841 and 1867 acts ....”); CHARLES WARREN, BANKRUPTCY IN UNITED STATES HISTORY 13 (1935) (noting that the initial bankruptcy bill introduced in the United States closely followed the English Bankruptcy Act); Tabb, supra note 254, at 6-7 ("The first United States bankruptcy law, passed in 1800 , virtually copied the existing English law.").

265 WARREN, supra note 264 , at 22 ; see also Countryman, supra note 261 , at 228 ("[T] he colonies and then the states had carried over the English system of imprisonment for debt and only some of the states had insolvency laws which would give the debtor a discharge or at least a release from jail.").

${ }^{266}$ Charles Jordan Tabb, The Historical Evolution of the Bankruptcy Discharge, 65 AM.

BANKR. L.J. 325, 338 (1991).

26711 U.S.C. $\S \S 101-1532(2006)$.

268 The concept of "keeping house" refers to the act of a debtor who intentionally seeks refuge in her home for the purpose of avoiding creditors and civil process. See Jay Cohen, The History of Imprisonment for Debt and Its Relation to the Development of Discharge in Bankruptcy, 3 J. LEGAL HIST. 153, 155 (1982); Rhett Frimet, The Birth of Bankruptcy in the United States, 96 CoM. L.J. 160, 163 (1991); see also Israel Treiman, Acts of Bankruptcy: A Medieval Concept in Modern Bankruptcy Law, 52 HARV. L. REV. 189, 194 (1938) ("This was the notorious practice of 'keeping house,' by which a debtor, protected by the sanctified English maxim that a man's house is his castle, would betake himself to his home and there consume his creditors' goods, utterly immune to forcible intrusion by legal process.'). 
judgments ... as may be necessary for the enforcement" of the provisions of the former Bankruptcy Act. ${ }^{269}$ As quoted above, $\S 105$ now enables bankruptcy courts to issue any necessary or appropriate orders to carry out the provisions of the Bankruptcy Code. ${ }^{270}$ As one commentator has argued, the inclusion of the language "or appropriate" signifies a liberalization of the limits of the powers of a bankruptcy court. ${ }^{271}$ No doubt, the ambiguity of the phrase "necessary or appropriate" can cause considerable judicial confusion. If viewed restrictively, then any order under $\S 105$ would need to be indispensable to furthering the provisions of the Bankruptcy Code. ${ }^{272}$ In such a case, the issuance of a search order would not be "necessary" in the technical sense because other remedies specifically exist under the Bankruptcy Code if a debtor is less than forthcoming in her disclosures. That is, a court can dismiss the bankruptcy case $^{273}$ or deny the debtor a discharge of preexisting debt. ${ }^{274}$ While a denial of discharge may appear to be a significant penalty for committing fraud, a denial of a discharge leaves the debtor in no worse of a position vis-à-vis her creditors than before filing for bankruptcy protection. ${ }^{275}$ In other words, after a denial of discharge, the existing creditors remain empowered to collect their debts from the debtor in personam ${ }^{276}$ as if the bankruptcy filing never occurred. A denial of discharge may do nothing to prevent debtor fraud ex ante or during the bankruptcy proceeding itself. ${ }^{277}$ But the issuance of a search order to uncover

${ }^{269} 11$ U.S.C. $\S 11(a)(15)(1976)$ (repealed 1978).

270 Id. $\$ 105$ (a) (2006).

${ }^{271}$ Brian Leepson, $A$ Case for the Use of a Broad Court Equity Power to Facilitate Chapter 11 Reorganization, 12 EMORY BANKR. DEV. J. 775, 795 (1996); see also Amanda K. Bloch, Approaching the Limits of the Bankruptcy Code: Does Surcharging a Debtor's Exempt Assets Go Too Far?, 76 U. CHI. L. REv. 1747, 1755 (2009) (noting that the language of $\S 105(\mathrm{a})$ provides bankruptcy courts with more power than its predecessor).

272 See Wacker, supra note 129, at 59 (making a similar argument, but under the All Writs Act).

${ }^{273}$ See 11 U.S.C. $\$ 1307$ (c) (enabling the court to dismiss a Chapter 13 case "for cause" upon request of the U.S. Trustee); see also id. $\S 707(\mathrm{a})$ (enabling the court to dismiss a Chapter 7 case "for cause").

274 Id. $\$ 727(\mathrm{a})(2)$.

275 Nevin M. Gewertz, Comment, Act or Asset? Multiplicitous Indictments Under the Bankruptcy Fraud Statute, 18 U.S.C. § 152, 76 U. CHI. L. REV. 909, 912 (2009) ("Significantly, however, civil penalties impose no greater penalty than the original debt itself. If successful in his fraudulent act, the debtor retains the value of any concealed assets[;] [i]f caught, the debtor remains in no worse position relative to his creditors."); see also Ralph C. McCullough, II, Bankruptcy Fraud: Crime Without Punishment, 96 CoM. L.J. 257,284 (1991) ("Demanding that a debtor restore to the estate assets he has appropriated will help make up what has been stolen, but it leaves the debtor no worse off than he would have been had he originally surrendered the assets. He risks nothing by attempting to hide assets that may later be recovered.").

${ }^{276}$ IRS v. Cousins (In re Cousins), 209 F.3d 38, 41 (1st Cir. 2000) ("The debtor remains personally liable, however, for any nondischargeable debts.").

${ }^{277}$ See James M. Cain, Proving Fraud in Credit Card Dischargeability Actions: A Permanent State of Flux?, 102 COM. L.J. 233, 239 n.31 (1997) (observing that the 
debtor fraud would certainly be appropriate given the strong policy favoring absolute candor by debtors involved in the bankruptcy process. Indeed, such an order would be appropriate to protect the integrity of the bankruptcy estate and to promote an accurate distribution of available assets to the creditor constituency. ${ }^{278}$

Commentators critical of an expansive reading of $\S 105$ do agree on this: since $\S 105$ is modeled after the All Writs Act, $\S 105$ jurisprudence "should be informed by the All Writs Act jurisprudence." 279 Thus, a conservative reader of $\S 105$ would therefore concede that if a search order could be issued pursuant to the All Writs Act, then a similar order could emanate from $\S 105$ of the Bankruptcy Code. Thus, we return to the inquiry of whether such relief was available under the All Writs Act. At least in the criminal law context, the U.S. Court of Appeals for the District of Columbia Circuit in Blackie's House of Beef, Inc. v. Castillo ${ }^{280}$ noted that the power to obtain search warrants "in aid of jurisdiction" under the All Writs Act is an available procedural device. ${ }^{281}$ But, as noted above, the issue is not free from doubt. If a court adopts a restrictive interpretation of $\S 105$, then it would decline a request by a trustee to have a search order issued for a debtor's residence. On the contrary, a court adopting a liberal interpretation of $\S 105$ might very well accept the notion that $\S 105$ is an appropriate vehicle for issuing a search order to a trustee, especially when Federal Rule of Criminal Procedure 41 does not apply and no Bankruptcy Code provision currently speaks to the issue.

\section{The Inherent Powers Doctrine as a Source of Authority for a Bankruptcy Court to Issue a Search Warrant}

A third possible, but admittedly unlikely, source of authority for a bankruptcy court to issue a search order is the "inherent powers" doctrine. ${ }^{282}$ It

withholding of a discharge is often an empty threat to debtors whose lack of assets removes any fear of civil remedies); Mary Jo Heston et al., Bankruptcy Fraud: A Roundtable Discussion, 6 AM. BANKR. INST. L. REV. 275, 279 (1998) (noting that actions to deprive a debtor of her discharge fail to deter attempts at fraud); Luther Zeigler, Note, The Fraud Exception to Discharge in Bankruptcy: A Reappraisal, 38 STAN. L. REV. 891, 917 (1986) (arguing that the penalty of nondischargeability is not an effective penalty for debtor fraud).

${ }^{278}$ In re N. Boneless Meat Corp., 9 B.R. 27, 29 (S.D.N.Y. 1981) (noting that section $2(a)(15)$ of the Bankruptcy Act, the precursor to $\S 105(a)$, may be used "to protect the integrity of a bankrupt's estate and the Bankruptcy Court's custody thereof').

279 J. Maxwell Tucker, Substantive Consolidation: The Cacophony Continues, 18 AM. BANKR. INST. L. REV. 89, 126 (2010); see also Bogart, supra note 218, at 830 ("The All Writs Act provides the best model for interpretation and application of section 105 of the Code.").

280659 F.2d 1211 (D.C. Cir. 1981 ).

281 Id. at 1222 .

282 For an exhaustive treatment of the inherent powers doctrine, see Joseph J. Anclien, Broader Is Better: The Inherent Powers of Federal Courts, 64 N.Y.U. ANN. SURV. AM. L. 37 (2008), Daniel J. Meador, Inherent Judicial Authority in the Conduct of Civil Litigation, 73 
has been said that when Congress provided the federal courts with subject matter jurisdiction, the courts became possessed with certain inherent powers. ${ }^{283}$ Bankruptcy courts, as units of the federal district courts, ${ }^{284}$ also have this authority. ${ }^{285}$ Federal courts regularly utilize their inherent powers to take some action that has not been specifically authorized by the Constitution, statute, or regulation. ${ }^{286}$ It has been repeatedly noted that federal courts "are invested with inherent powers that are 'governed not by rule or statute but by the control necessarily vested in courts to manage their own affairs so as to achieve the orderly and expeditious disposition of cases."'287

These inherent powers fall into three categories. The first category delineates activity "so fundamental to the essence of a court as a constitutional tribunal that to divest the court of absolute command within this sphere is really to render practically meaningless the terms 'court' and 'judicial power."'288 Stated differently, once Congress has created an Article III court, the Constitution vests certain powers thereto into which the other branches of government may not interfere. ${ }^{289}$ There are few examples of this type of inherent power. However, in United States v. Klein, the Supreme Court seems to hold that Congress may not interfere with a court's inherent power to decide a matter by dictating a particular result. ${ }^{290}$ It is safe to assume that the specter of a bankruptcy court issuing a search order would not fall into this first category of inherent power.

The second category of inherent powers includes those "necessary to the exercise of all others." 291 These powers have been construed to mean "those

TeX. L. Rev. 1805 (1995), Robert J. Pushaw, Jr., The Inherent Powers of Federal Courts and the Structural Constitution, 86 IowA L. REV. 735 (2000), William F. Ryan, Rush to Judgment: A Constitutional Analysis of Time Limits on Judicial Decisions, 77 B.U. L. REV. 761 (1997), and William W. Van Alstyne, The Role of Congress in Determining Incidental Powers of the President and of the Federal Courts: A Comment on the Horizontal Effect of the Sweeping Clause, LAW \& CONTEMP. PROBS., Spring 1976, at 102.

${ }^{283}$ Ex parte Robinson, 86 U.S. 505, 510 (1873).

${ }^{284}$ See 28 U.S.C. $\$ 151$ (2006) ("In each judicial district, the bankruptcy judges in regular active service shall constitute a unit of the district court to be known as the bankruptcy court for that district.").

285 John Richards Homes Bldg. Co. v. Adell (In re John Richards Homes Bldg. Co.), 404 B.R. 220, 226 (E.D. Mich. 2009) (holding that bankruptcy courts have the inherent power to issue sanctions); In re Cabrera-Mejia, 402 B.R. 335, 346 (Bankr. C.D. Cal. 2008) ("In addition, all federal courts, including bankruptcy courts, have inherent powers to enforce their orders and judgments." (citing Caldwell v. Unified Capital Corp. (In re Rainbow Magazine, Inc.), 77 F.3d 278, 284 (9th Cir. 1996))); Nickles \& Epstein, supra note 228 , at 10 .

286 Anclien, supra note 282 , at 38 .

${ }^{287}$ Unigard Sec. Ins. Co. v. Lakewood Eng'g \& Mfg. Corp., 982 F.2d 363, 368 (9th Cir. 1992) (quoting Chambers v. NASCO, Inc., 501 U.S. 32, 43 (1991)).

288 Eash v. Riggins Trucking Inc., 757 F.2d 557, 562 (3d Cir. 1985).

${ }^{289}$ In re Stone, 986 F.2d 898, 901 (5th Cir. 1993).

290 Id. (citing United States v. Klein, 80 U.S. (13 Wall.) 128, 146-47 (1872)).

${ }^{291}$ Id. at 902 (citing Roadway Express, Inc. v. Piper, 447 U.S. 752, 764 (1980)). 
deemed necessary to protect the efficient and orderly administration of justice and those necessary to command respect for the court's orders, judgments, procedures, and authority." 292 Examples of this stripe of inherent power include the contempt sanction, ${ }^{293}$ the ability to levy sanctions in response to abusive litigation practices, ${ }^{294}$ the imposition of standards for admission to the bar, 295 the flexibility to vacate judgments if tainted by fraud, ${ }^{296}$ the dismissal of an action for failure to prosecute, ${ }^{297}$ the inclusion or exclusion of evidence during trial, 298 and the consolidation of actions arising out of the same controversy. ${ }^{299}$ As Professors Nickles and Epstein note, this inherent power is limited to process closely related to the proper functioning of a tribunal. ${ }^{300}$ While concealing assets contradicts a debtor's duties under the Bankruptcy Code ${ }^{301}$ and offends the policy underlying consumer bankruptcy law, such conduct does not inhibit the proper functioning of the bankruptcy court as a tribunal. As such, this type of inherent power would not provide a court with an ability to issue a search warrant.

The third category of inherent powers includes "those reasonably useful to achieve justice." 302 With respect to this category, the U.S. Court of Appeals for the Fifth Circuit has stated as follows: "[T]he legislature cannot foresee every tool the courts might need to employ to reach a just result in all cases. Where it appears that a court cannot adequately and efficiently carry out its duties without employing some special device, the court has inherent power to do so." 303 This third category of inherent powers seemingly overlaps with both the All Writs Act and $\S 105$ insofar as it serves as an interstitial tool for courts to achieve a just result. ${ }^{304}$ Indeed, regarding the capacity of a federal court to issue

292 Id.

293 Piper, 447 U.S. at 764.

294 Stone, 986 F.2d at 902.

${ }^{295} \mathrm{Ni}$ v. Gonzales, 494 F.3d 260, 267 (2d Cir. 2007).

296 Id.

${ }^{297}$ United States v. Moussaoui, 483 F.3d 220, 236 (4th Cir. 2007).

${ }^{298}$ Unigard Sec. Ins. Co. v. Lakewood Eng'g \& Mfg. Corp., 982 F.2d 363, 368 (9th Cir. 1992) (excluding insurer's expert testimony evidence).

299 Moussaoui, 483 F.3d at 236.

300 Nickles \& Epstein, supra note 228, at 9.

${ }^{301}$ Pursuant to $\S 521(\mathrm{a})(1)(\mathrm{B})(\mathrm{i})$ of the Bankruptcy Code, a debtor must file a schedule of all assets and liabilities. 11 U.S.C. $\S 521(\mathrm{a})(1)(\mathrm{B})(\mathrm{i})$ (2006). In addition, $\S 521(\mathrm{a})(4)$ requires that if a trustee is appointed in a case, the debtor must surrender all property of the estate to the trustee. $I d$. $\S 521$ (a)(4).

302 In re Stone, 986 F.2d 898, 902 (5th Cir. 1993) (citing Eash v. Riggins Trucking Inc., 757 F.2d 557, 563 (3d Cir. 1985)).

${ }^{303}$ Id. (citing Ex parte Peterson, 253 U.S. 300, 312 (1920)). An example of this third category of inherent power is the ability of a federal court to appoint an auditor to aid in resolving a complex commercial matter. Id.

304 ITT Cmty. Dev. Corp. v. Barton, 569 F.2d 1351, 1360 (5th Cir. 1978) ("The doctrine of inherent powers, as we have indicated, provides a federal court 'with appropriate instruments required for the performance of [its] duties' and essential to the administration of justice." (alteration in original) (quoting Ex parte Peterson, 253 U.S. at 312)). 
a writ of injunction under its inherent powers, ${ }^{305}$ courts have concluded that the power is conterminous with a federal court's authority under the All Writs Act. 306

While again reflecting on the All Writs Act as an appropriate guide to a federal court's powers under its inherent authority is what may be called for, there are at least two valid reasons for declining to do so. First, unlike the All Writs Act, which is a statutory delegation of authority to federal courts for the specific purpose of issuing necessary or appropriate writs, the court's inherent powers do not require the endorsement of Congress; indeed, when courts exercise their inherent powers, they "essentially create their own procedural rules" without the endorsement of Congress. ${ }^{307}$ Accordingly, this raises a potential separation of powers concern, as it is the responsibility of Congress to make both substantive and procedural federal law, which the federal courts are in turn charged with simply interpreting and applying. ${ }^{308}$ Indeed, commentators on the inherent powers doctrine have argued that the use of a federal court's inherent powers is impermissible when adopting practices in the absence of a controlling statute or rule of procedure.$^{309}$ Rather, these scholars contend that the reliance upon a federal court's inherent powers should be made only when "indispensably necessary" to achieving a court's fundamental purpose, namely, the adjudication of actual controversies. ${ }^{310}$ Second, unlike the developed contours of the All Writs Act, "[t]here is no clear standard establishing when courts may legitimately invoke their inherent powers to take some action that has not been specifically licensed by rule or statute." 311 The instances in which

305 A writ of injunction would be the order most equivalent to the issuance of an order compelling a search of a debtor's home.

306 Peters v. Brants Grocery, 990 F. Supp. 1337, 1343 (M.D. Ala. 1998) ("It is clear to the court, based on its reading of the applicable case law, that a court's authority to issue an injunction against other litigation under its inherent powers is no broader than its authority under the All Writs Act."). On this note, the United States Court of Appeals for the Fifth Circuit concluded as follows in ITT Community Development Corp. v. Barton:

At first blush it might appear that inherent powers are broader in scope than those conferred by the All Writs Act because of the absence of a reference to 'jurisdiction.' The limitation that inherent powers be used only as required for the performance of duties suggests, however, that the exigencies of the pending litigation dictate the breadth of a court's discretion to invoke these powers just as they operate to bridle a court's discretion under the All Writs Act.

Barton, 569 F.2d at 1360.

307 Anclien, supra note 282, at 39.

308 Pushaw, supra note 282 , at 739 .

${ }^{309}$ See id. at 743 (arguing that federal courts should be barred from asserting any "beneficial powers"); see also Ryan, supra note 282, at 776, 779 (describing this as a "weak" version of a federal court's inherent power); Van Alstyne, supra note 282, at 107 (arguing that the courts should not be permitted to exercise any inherent power unless there is an indispensable need to do so).

310 Anclien, supra note 282 , at 49 .

311 Id. at 41 . 
a court has utilized its inherent powers, such as sanctioning counsel or dismissing a case for lack of prosecution, seem to be far removed from the issuance of an order authorizing a state actor to search the home of a private citizen.

\section{CONCLUSION}

As stated at the outset, the purpose of this Article is to offer a reasonable answer to a question that has not been raised by the case law or the academic literature. ${ }^{312}$ Admittedly, one way to obviate the issue of a bankruptcy trustee's ability to seek a search order would be for the trustee to refer the matter to a federal law enforcement officer or to the appropriate U.S. Attorney's Office who in turn would request a search warrant on the trustee's behalf. Doing so would circumvent the need for a court to rely upon either the All Writs Act or $\S 105$ as its source of authority, and cause Federal Rule of Criminal Procedure 41 to come into play. This route, however, would prove impractical for at least two reasons.

First, as it currently stands, in general the U.S. Attorneys' Offices around the country have been reluctant to devote scarce resources for the prosecution of bankruptcy crimes, so requiring a trustee to make a referral and wait for the appropriate U.S. Attorney's Office to act would not accomplish much to combat debtor fraud. Second, the need for trustees to act quickly is imperative because assets most debtors possess are easily transferrable or hidden. Consequently, if there are pronounced time delays between a referral for a warrant and the ensuing application by a federal law enforcement officer or an Office of the U.S. Attorney, an undeserving debtor may succeed in abusing the bankruptcy system.

Other ways to remedy the void are for Congress either to amend the Bankruptcy Code to provide bankruptcy courts with the ability to issue administrative search warrants upon application by a bankruptcy trustee, in accordance with established Fourth Amendment parameters, or, as suggested by Professor A. Mechele Dickerson, to revise the Bankruptcy Code to provide that one of a debtor's duties is to consent to a search of her home. ${ }^{313}$ There is no question that either of these solutions would be best. However, this issue is not at the forefront of Congress's agenda, and it may never be.

Thus, what is left is a casus omissus. In order to fill this void and prevent future fraudulent conduct by undeserving debtors, bankruptcy courts should rely upon either the All Writs Act or $\S 105$ of the Bankruptcy Code in combating such activity.

312 For the scholarly literature on the intersection between bankruptcy law and the Fourth Amendment, see A. Mechele Dickerson, Can the "Public Interest" Justify NonConsensual Searches of Homes in Bankruptcy Cases?, 11 WM. \& MARY BILL RTS. J. 267 (2002); Kuretich, supra note 169, Sousa, supra note 5, and Jennifer Taylor, Note, Some Bargain: How Bankruptcy Courts May Now Require a Debtor to Relinquish Expectations of Privacy as a Condition of the Bankruptcy Bargain, 56 HASTINGS L.J. 609 (2004).

${ }^{313}$ Dickerson, supra note 312, at 302. 
